\title{
GEODIVERSITY AND BIODIVERSITY OF THE POSTGLACIAL LANDSCAPE (DĘBNICA RIVER CATCHMENT, POLAND)
}

\author{
Alicja Najwer ${ }^{1}$, Janina Borysiak², Joanna Gudowicz ${ }^{1}$, MaŁgorzata MazureK ${ }^{1}$, \\ ZBIGNIEW ZWOLIŃSKI ${ }^{1}$
}

\author{
${ }^{1}$ Institute of Geoecology and Geoinformation, Adam Mickiewicz University in Poznań, Poland \\ ${ }^{2}$ Institute of Physical Geography and Environmental Planning, Adam Mickiewicz University in Poznań, Poland
}

Manuscript received: September 8, 2015

Revised version: February 11, 2016

\begin{abstract}
Najwer A., Borysiak J., Gudowicz J., Mazurek M., Zwoliński Zв., 2016. Geodiversity and biodiversity of the postglacial landscape (Dębnica River catchment, Poland). Quaestiones Geographicae 35(1), Bogucki Wydawnictwo Naukowe, Poznań, pp. 5-28, 12 figs, 4 tables.

ABSTRACT: The preparation of a proper zoning plan or landscape-ecological plan requires taking into account recognition of the natural values of an area covered by the plan and evaluating its abiotic and biotic diversities. The aim of the paper is to present the new approach to the procedure of geodiversity and biodiversity assessment. This procedure is used to characterise abiotic and biotic heterogeneity of the postglacial landscape modified by a man, tested on Dębnica River catchment (Western Pomerania, Poland). This catchment is a representative example illustrating the landscape of Central European Plain. The analytical algorithm of the geodiversity assessment is based on appropriate selection of the evaluation criteria: lithological, relative heights, landform fragmentation, hydrographical elements and mesoclimatic conditions. Biodiversity was assessed on the basis of real vegetation, potential natural vegetation and the degree of anthropisation of the natural vegetation with respect to syngenesis of plant associations. Seven factor maps were obtained: five for the diversity of abiotic elements, and two for the diversity of biotic elements, which became the basis for the creation of total geodiversity and biodiversity maps. Maps produced in accordance with given methodology may find a wide range of applications.
\end{abstract}

KEYWORDS: geodiversity, biodiversity, diversity assessment, diversity mapping, Western Pomerania, Poland

Corresponding author: Alicja Najwer (alijas@amu.edu.pl)

\section{Introduction}

Natural environment consists of a variety of correlated abiotic and biotic systems, which are responsible for diversity in nature (Serrano, RuizFlaño 2009). Geodiversity determines biodiversity but occasionally an inverse relationship may occur, e.g. the impact of diversity and multiplicity of species on the character of organogenic sediments on the biogenic plains. Despite the existing dependency of biodiversity on geodiversity, the current legal systems protect mostly biotic nature (Kistowski 2012). This is reflected in the development of the assessment methods of biodiversity, while the research on geodiversity is neglected (Najwer, Zwoliński 2014a, Borysiak 2015, Speak et al. 2015).

Duff (1994) defines geodiversity as abiotic variability and argues that certain elements of the geological substrate are reflected in the richness and diversity of plant species in a given research area. Numerous connotations of geodiversity have been recognised by Najwer and Zwoliński (2014a). 
Geodiversity as a basis for the analysis of biodiversity is primarily found in German studies (Leser 1997, Barthlott et al. 1999, Jedicke 2001). Jedicke (2001: 60) defines geodiversity as variability in the abiotic elements and components in a hierarchical ecological system, such as geology, topography, surface water and groundwater, weather conditions and soil cover. They form spatially functioning relational systems (physiotops), and together with biodiversity, create an ecodiversity. The diversity of abiotic conditions is unfortunately treated as a secondary variable (Najwer, Zwoliński 2014a). According to Ratajczak-Szczerba (2013), biodiversity is usually a kind of a showcase and one of the elements used in tourism promotion, particularly in lowland areas. The role of geodiversity for geotourism is, however, underestimated (Ollier 2012, Thomas 2012), and its potential not fully utilised.

The research problems undertaken since the turn of the 20th and 21st century, consider geodiversity integrated with the natural habitats and landscapes (Silva 2004, Jačková, Romportl 2008, Alexandrowicz, Margielewski 2010, Parks, Mulligan 2010, Virtanen et al. 2010, Pellitero et al. 2010, Hjort et al. 2012, Kistowski 2012, Hjort et al. 2015), and even cultural heritage (Mazurek et al. 2015). The preparation of a good zoning plan or landscape-ecological plan (Pauditšová, Reháčková 2010, Łowicki 2014) requires taking into account the existing and possibly appointing new nature reserves, specifying the directions of their management. This condition can only be met via recognising the natural values of the area covered by the plan and by evaluating its abiotic and biotic diversity.

The aim of the paper is to present a new unified assessment procedure for geodiversity and biodiversity, as well as establishing characteristics of abiotic and biotic heterogeneity of the postglacial landscape modified by a man. Dębnica River catchment, illustrating a model landscape for Central European Plain, was selected as a test area. Geodiversity evaluation will be based on the method specified for two mountainous river catchments of the Swiss Alps (Jaskulska et al. 2013, Najwer et al. 2014, Najwer, Zwoliński 2014a, b), as well as Tatra and Karkonosze Mts. (Najwer, Zwoliński 2014a, b). It was decided that the methodological assumptions for the mountainous areas would be applied for the postglacial area, which is characterized by relatively high relief energy against the background of geomorphometrically various lowland areas of the Central European Plain. Biodiversity is mainly determined on the basis of the analysis and the assessment of abiotic characteristics of the study area, i.e. land cover and land use types, but supplemented by types of real and potential vegetation. This is not a direct determination of the species diversity, but a reference to the impact of geodiversity on biodiversity. This approach is an attempt to integrate geodiversity and biodiversity assessments for the lowland areas of the postglacial origin.

\section{Study area}

The research was carried out in Dębnica River catchment located in Western Pomerania, north-western Poland. Study area of $289.1 \mathrm{~km}^{2}$ belongs to two macro-regions: West Pomeranian Lake District and Koszalin Coastland (Kondracki 2000, Fig. 1). The topography of Dębnica catchment partly reflects the pre-Quaternary substrate and the landforms formed during earlier glaciations. The processes of glacial and fluvioglacial erosion and accumulation occurring during Weichselian glaciation as well as postglacial Holocene processes of erosion and denudation influenced the creation of contemporary topography of not only this region, but also the entire morphogenetic postglacial zone (Zwoliński et al. 2008), where Dębnica catchment is located.

The diversity of geomorphological processes that shaped the relief of Dębnica catchment is reflected in the lithological diversity of surface sediments. Different sedimentary series and their sequences are the result of the direct glacial accumulation, as well as glaciofluvial waters activity of the Weichselian glaciation (Karczewski 1989, Kłysz 1990). The youngest sedimentary series were the effect of the fluvial, aeolian and organogenic accumulation. The structure of the soil cover of the catchment area has been described as "irregularly patched", and as including "strip ordered" structures (Prusinkiewicz, Bednarek 1991).

The valley network in Dębnica catchment reflects the layout of the depressions of glacial, fluvioglacial, fluvial and denudation genesis. Dębnica is the left tributary of Parsęta River, with a length of 39.6 $\mathrm{km}$ and a main stream slope of $2.9 \%$. The rhythm of fluvial processes, climatically conditioned in the last 3-4 thousand years, has been variously distorted due to human interference. Since the nineteenth 
century Pomerania witnessed regulatory and drainage works that changed the length, slope and longitudinal profiles of many river channels (Florek 1991, Szpikowski 2010, Szpikowski et al. 2015), and disturbed the sediment balance between erosion and accumulation in river valleys.

According to the geobotanical division of Poland, based on the potential natural vegetation (Matuszkiewicz 2008), Dębnica River catchment is located in the Land of the Central Pomeranian Lake Region. Its area is dominated by the potential biochore of mix pine forest (Querco-Pinetum) and rich beech forest (Melico-Fagetum). The river valley slopes are the domain of oak-hornbeam forest habitat (Stellario-Carpinetum) and the valley bottoms are the area of ash-alder forest habitat (FraxinoAlnetum). After 1989 significant changes of the real vegetation in the catchment area have taken place as a result of the ongoing systemic transformation in Poland (Winiecki 2012). Among other things, agricultural lands of low economic efficiency have been abandoned. As a result, poor sandy arable land with deep groundwater table has been spontaneously overgrown by vegetation composed of mainly native species. The same process, i.e. spontaneous, secondary biocoenotic regeneration succession, was observed within the non-mowed and non-grazed grasslands. As a result of this succession, non-forest anthropogenic phytocoenosis in many parts of the catchment, especially in the river valleys with the potential natural vegetation habitats of alder (Ribeso nigri-Alnetum) and riparian (Fraxino-Alnetum), has been replaced by forest habitats and hemeroby index is successively decreasing. The reduction of the anthropisation level and increase in the natural biodiversity was caused by the cessation of farming activity in many areas of former state farms around 1989 (Borysiak et al. 2014).

Currently, Dębnica catchment shows forestry-agricultural use, where forest areas account for $51.6 \%$, and agricultural for $42.9 \%$ calculated from CORINE Land Cover 2006 (EEA 2006) and

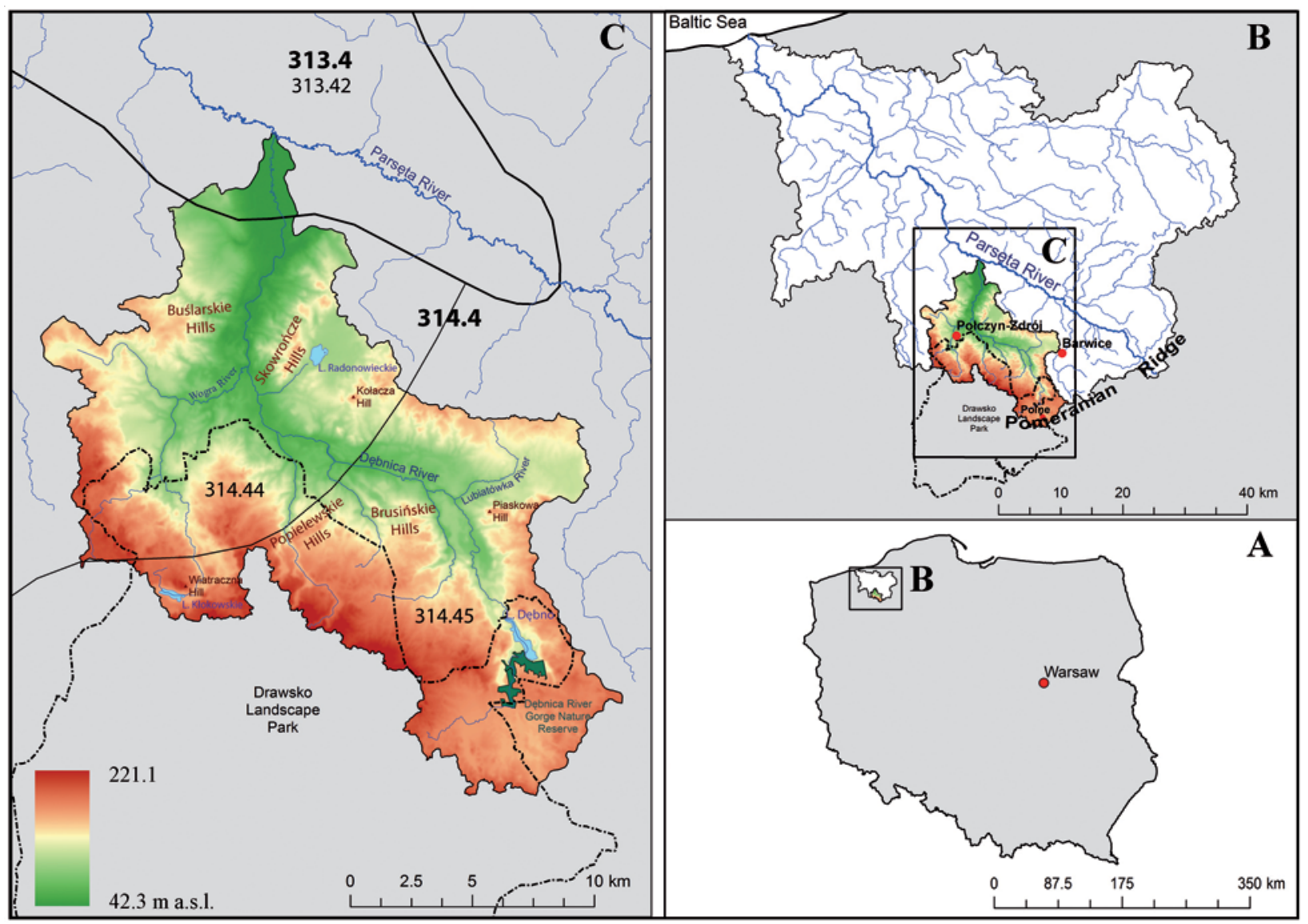

Fig. 1. Digital elevation model and location of Dębnica catchment on the physical-geographical division of Poland (after Kondracki 2000). 313.4 - Koszalin Coastland (313.42 - Białogardzka Plain), 314.4 - West Pomeranian Lake District (314.44 - Łobeska Upland, 314.45 - Drawskie Lake District). 
supplemented by field mapping. Grasslands are mainly related to the drained mineral-organic and organic soils, occurring in large kettle-hole and valleys. They represent a total of slightly more than $5 \%$ of the catchment area. Forests include coniferous $(21.6 \%)$, deciduous $(14.9 \%)$ and mixed $(11.8 \%)$ communities. In the research area economic and industrial activity is concentrated mainly in the city of Połczyn-Zdrój. Anthropogenically transformed areas represent $4 \%$ of the catchment area, whereas oxbow lakes and eutrophic water bodies $-1.5 \%$. Part of Dębnica catchment belongs to Drawsko Landscape Park and its a buffer zone.

\section{Methods}

In light of the explicit purposes of this paper it was important to correctly determine the current status of the geographical environment both from the point of view of its geodiversity and biodiversity. This condition allows the assessment of the suitability of abiotic and biotic natural conditions to perform specific functions and influences the forecast of changes in the environment (Richling, Solon 2011). The research procedure presented below was fitted into the overall geodiversity assessment scheme proposed by Najwer, Zwoliński (2014a), referring in a modified way to the method of point bonitation (Bartkowski 1977, Sołowiej 1992, Bródka 2010, Macias, Bródka 2014, Kot 2006, 2014).

Analogue and digital input data (Table 1), i.e. a digital elevation model DTED2 (NGIA 2004), sheets of the Detailed Geological Map of Poland (published by State Geological Institute), Map of Hydrographical Division of Poland (IMGW 2007) and the results from hydrographic field mapping, have been integrated on the geoinformation platform ArcGIS 10. The analytical algorithm was based on an appropriate selection of the evaluation criteria in reference to the definition of geodiversity (Gray 2004, 2013, Zwoliński 2004). Geodiversity was assessed on the basis of five general criteria (Table 1), which characterise geodiversity of the area in the fullest possible way. Taking into account the resolution of the source data and their field detailing, the size of the grid cell was set at $30 \times 30 \mathrm{~m}$. Most of the analysis have been carried out in the software ArcGIS 10.

The first factor map, i.e. of the lithological diversity, was based on the expert classification of 19 types of deposits, mainly glacial and fluvioglacial, into 5 geodiversity classes (Table 1). The assessment criterion was the vulnerability of the identified deposits to the rate of relief evolution, i.e. the intensity of erosion and denudation processes and the ability to preserve the original landscape made up of these deposits. The study used the following sheets of the Detailed Geological Map of Poland, at the scale 1:50,000: Dobrowo (Dobracka 2001), Połczyn-Zdrój (Dobracka 2009), Barwice (Popielski 2000) and Łubowo (Lewandowski et al. 2006).

The next factor map uses a digital elevation model and the natural breaks classification method (Jenks 1967) to show the diversity of relative (local) heights, which reflects the energy of the relief (Zwoliński 2008, 2009). These values were calculated for each grid cell by analysing the neighbourhood (Focal Statistics), in a $3 \times 3$ grid cells moving window (Zwoliński, Stefańska 2015) and reclassified into 5 classes of geodiversity (Table 1 ).

Another criterion, using a digital elevation model, was the factor map of the landform fragmentation. For this purpose an algorithm for calculation and semi-automatic classification of the Topographic Position Index - TPI (Weiss 2001) was used, which is implemented in the Land Facet Corridor Designer (Jenness et al. 2011) in ArcGIS. The algorithm recognises six main classes of morphologic landforms, separated by breakpoints (using standard deviation units): ridge, upper slope, middle slope, flat slope, lower slope and valley (Weiss 2001). Calculations were made in many variants of the neighbourhood of a moving window (Zwoliński, Stefańska 2015) so that the result best characterised the topography of the test area. A circle of a radius of 100 grid cells was chosen experimentally. The distinguished landforms were expertly reclassified into 5 geodiversity classes (Table 1 ).

The most complex factor map is the map of hydrographical elements diversity, which is the result of the map algebra (adding function) of three fragmentary maps showing diversity of lakes, rivers and groundwater outflows. The fractional assessment referring to lakes depended on the surface area and shoreline development index, referring to stream reaches depended on their longitudinal slope, and referring to outflows of groundwater depended on their type and discharge. The calculated or measured parameters were divided into 5 geodiversity classes using Jenks (1967) natural breaks classification method. Due to their point nature, 
Table 1 . The criteria for the assessment of geodiversity values for particular factor maps.

\begin{tabular}{|c|c|c|c|c|}
\hline $\begin{array}{c}\text { Factor } \\
\text { maps }\end{array}$ & Source data & Classification method & Parameters and criteria & $\begin{array}{l}\text { Geodiversity } \\
\text { value }\end{array}$ \\
\hline \multirow{5}{*}{ 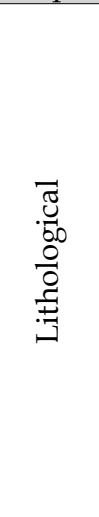 } & \multirow{5}{*}{$\begin{array}{l}\text { Detailed } \\
\text { geological } \\
\text { map of } \\
\text { Poland } \\
1: 50,000\end{array}$} & \multirow[t]{5}{*}{ Expert classification } & $\begin{array}{l}\text { peats; loams; humus sands; gyttjas and lacustrine } \\
\text { chalk; calcareous tufa }\end{array}$ & 1 - very low \\
\hline & & & $\begin{array}{l}\text { lake sands, silts and clays; ice-dammed clays, silts } \\
\text { and sands }\end{array}$ & $2-$ low \\
\hline & & & $\begin{array}{l}\text { glacial sands and gravels; outwash sands and grav- } \\
\text { els; fluvioglacial sands and gravels; kame sands and } \\
\text { silts; sands and gravels of crevasse accumulation } \\
\text { and eskers; alluvial sands of valley floors and flood- } \\
\text { plains; alluvial sands of river terraces; aeolian sands }\end{array}$ & 3 - medium \\
\hline & & & $\begin{array}{l}\text { end-moraine gravels, sands, boulders and tills; col- } \\
\text { luvial sands and clays }\end{array}$ & 4 - high \\
\hline & & & glacial tills & 5 - very high \\
\hline \multirow{5}{*}{ 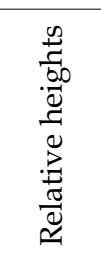 } & \multirow{10}{*}{$\begin{array}{l}\text { 30-meter } \\
\text { Digital } \\
\text { Elevation } \\
\text { Model } \\
\text { (DTED 2) }\end{array}$} & \multirow{5}{*}{$\begin{array}{l}\text { Automatic } \\
\text { classification with } \\
\text { a natural breaks } \\
\text { method (Jenks 1967) }\end{array}$} & Hw: $0-2.3 \mathrm{~m}$ & 1 - very low \\
\hline & & & Hw: $2.4-4.5 \mathrm{~m}$ & $2-$ low \\
\hline & & & Hw: $4.6-7.5 \mathrm{~m}$ & 3 - medium \\
\hline & & & Hw: 7.6-11.8 m & 4 - high \\
\hline & & & Hw: 11.9-29.7 m & 5 - very high \\
\hline \multirow{5}{*}{ 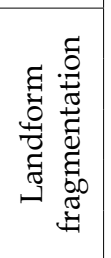 } & & \multirow{5}{*}{$\begin{array}{l}\text { Semi-automatic } \\
\text { classification and } \\
\text { expert classification }\end{array}$} & valleys; lower slopes & 1 - very low \\
\hline & & & gentle slopes & $2-$ low \\
\hline & & & upper slopes & 3 - medium \\
\hline & & & steep slopes & 4 - high \\
\hline & & & ridges & 5 - very high \\
\hline \multirow{15}{*}{ 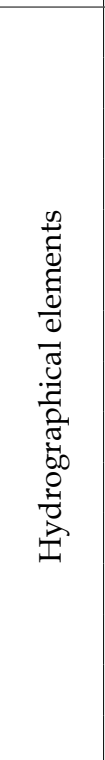 } & \multirow{15}{*}{$\begin{array}{l}\text { Map of } \\
\text { Hydrological } \\
\text { Division of } \\
\text { Poland in the } \\
\text { scale 1:50,000; } \\
\text { field mapping }\end{array}$} & \multirow{15}{*}{$\begin{array}{l}\text { Automatic } \\
\text { classification with } \\
\text { a natural breaks } \\
\text { method (Jenks 1967) }\end{array}$} & A: $0.0-0.6$ ha; $\mathrm{K}: 77-579 \mathrm{~m} \mathrm{ha}^{-1}$ & \multirow[t]{3}{*}{1 - very low } \\
\hline & & & S: $0.0-1.2 \%$, Br: $250 \mathrm{~m}$ & \\
\hline & & & Qz: 0-1 1 s $\mathrm{s}^{-1}$; type: linear seep, Bz: $30 \mathrm{~m}$ & \\
\hline & & & A: 0.7-2.7 ha; K: 580-955 m ha-1 & \multirow[t]{3}{*}{$2-$ low } \\
\hline & & & S: $1.3-2.4 \%$; Br: $150 \mathrm{~m}$ & \\
\hline & & & Qz: 1-5 $1 \mathrm{~s}^{-1}$; type: bog-spring, Bz: $60 \mathrm{~m}$ & \\
\hline & & & A: $2.8-7.2$ ha; K: 956-1235 $\mathrm{m} \mathrm{ha}^{-1}$ & \multirow[t]{3}{*}{3 - medium } \\
\hline & & & S: 2.5-4.0\%o; Br: $100 \mathrm{~m}$ & \\
\hline & & & Qz: 5-10 $1 \mathrm{~s}^{-1}$; type: seepage spring, Bz: $90 \mathrm{~m}$ & \\
\hline & & & A: 7.3-23.7 ha; K: 1236-1508 m ha-1 & \multirow[t]{3}{*}{4 - high } \\
\hline & & & S: 4.1-7.1\%o; Br: $50 \mathrm{~m}$ & \\
\hline & & & Qz: $10-201 \mathrm{~s}^{-1}$; spring and linear outflows, Bz: $120 \mathrm{~m}$ & \\
\hline & & & A: $23.8-56.1$ ha; K: $1509-2245 \mathrm{~m} \mathrm{ha}^{-1}$ & \multirow[t]{3}{*}{5 - very high } \\
\hline & & & S: 7.2-16.1\%o; Br: 25 m & \\
\hline & & & Qz: $10-1001 \mathrm{~s}^{-1}$; type: seepage spring area, Bz: $150 \mathrm{~m}$ & \\
\hline \multirow{5}{*}{ 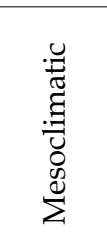 } & \multirow{5}{*}{$\begin{array}{l}\text { 30-meter } \\
\text { Digital } \\
\text { Elevation } \\
\text { Model } \\
\text { (DTED 2) }\end{array}$} & \multirow{5}{*}{$\begin{array}{l}\text { Automatic } \\
\text { classification with } \\
\text { a natural breaks } \\
\text { method (Jenks 1967) }\end{array}$} & TWI: 8.4-10.5; $\mathrm{K}^{\downarrow}: 2.1-3.8 \mathrm{kWh} \mathrm{m}{ }^{-2}$ & 1 - very low \\
\hline & & & TWI: 10.6-11.5; K`: 3.9-4.1 kWh m-2 & $2-$ low \\
\hline & & & TWI: 11.6-12.6; K': 4.2-4.3 kWh m² & 3 - medium \\
\hline & & & TWI: 12.7-13.9; K`: 4.4-4.5 kWh m² & 4 - high \\
\hline & & & TWI: 14-17.9; $\mathrm{K}^{\downarrow}: 4.6-5.6 \mathrm{kWh} \mathrm{m}^{-2}$ & 5 - very high \\
\hline
\end{tabular}

Symbols: Hw - relative height, TPI - Topographic Position Index, A - lake surface area, K - shoreline development index, $\mathrm{S}$ - reaches with the average slope, $\mathrm{Br}$ - buffer along the stream reaches with a radius of..., Qz - groundwater discharge, $\mathrm{Bz}$ - buffer around the groundwater outflows with a radius of..., TWI - Topographic Wetness Index, $\mathrm{K} \downarrow$ - Total Insolation 
groundwater outflows had a buffer zone added of a various radius: $30,60,90,120$ or $150 \mathrm{~m}$, resulting from the influence of a specific outflow on the environment as well as their discharge. In this way protection zones of spring areas were considered (Water Law 2001). A similar procedure was used for stream reaches. In this case, the buffer size varied depending on the longitudinal slope of the stream reaches in accordance with the principle that the smaller the slope the wider the buffer, which means a larger impact of the valley bottom and a lower valley slope on the development of the riverbed (Table 1). All calculations were made using both the Map of Hydrographical Division of Poland (IMGW 2007) and a digital elevation model.

The map of mesoclimatic diversity is derived from the sum of two selected geomorphometric parameters determining the intensity of processes which may change the topography of the area and which result from microclimatic and topoclimatic conditions, i.e. Topographic Wetness Index TWI (Beven, Kirkby 1979) and Total Insolation (ESRI 2015). These two indices, although calculated on the basis of the digital elevation model, are associated with two meteorological elements, namely precipitation and air temperature, and therefore they optimally characterise climatic conditions in the area (Zwoliński et al. 2008) from the morphoclimatic point of view (Zwoliński, Gudowicz 2015). Calculations were made using digital elevation model and the software Saga GIS 2.0.8., and then the resulting continuous maps were reclassified into 5 geodiversity classes using the Jenks (1967) natural breaks classification method (Table 1) and aggregated using the Weighted Sum tool.

A key step in the implementation of the geodiversity map in the Multi-Criteria Evaluation (MCE) using the Analytic Hierarchy Process (AHP) is to calculate properly the selected weights for particular factor maps of abiotic diversity from the point of view of their potential impact on the overall geodiversity of the study area. The calculation of weight is carried out by pairwise comparison by Saaty (1977, 1980, 1994), which is implemented in the software IDRISI Selva. The following weight values were calculated for individual factor maps of abiotic diversity: landform fragmentation -0.36 , relative heights - 0.35, hydrographical elements - 0.18, lithology 0.08 , and mesoclimate -0.03 . Maps were integrated using the Weighted Sum tools in ArcGIS. The final step of the research procedure was reclassification to 5 total value classes of geodiversity: very low, low, medium, high and very high, in order to better visualise homogeneous spatial units.

Biodiversity was assessed on the basis of the types of land cover and land use as well as their spatial distribution. Source data was obtained from the database CORINE Land Cover 2006 (EEA 2006) and updated during the field mapping in the years 2011-2014. The update concerns the diversification of the real vegetation, potential natural vegetation and the degree of anthropisation of the natural vegetation. The scope and methods for biodiversity research are presented in Figure 2.

The real vegetation was inventoried in the field in the years 2011-2014 at the level of phytocoenotic diversity. The inventory results were summarised in the form of a list of plant communities according to the phytosociological system of Brzeg and Wojterska (2001), and Matuszkiewicz (2012). Plant associations were grouped into the homologous series of dynamic circles of substitute associations, according to the concept of Matuszkiewicz (1974). In forest areas their ranges were based on the data from the management plans for forest divisions, as well as the algorithms provided by Pawlaczyk et al. (2003), based on the taxation description of the tree stand and forest habitat type. The characteristics of forest habitats were given by Sikorska (1999). For arable land and grassland the ranges of potential natural vegetation units were based on ranges of complexes of agricultural suitability of soils. The ranges of the complexes were taken from pedological-agricultural maps for municipalities (lowest administrative units in Poland) located within Dębnica River catchment: Barwice, Borne Sulinowo, Czaplinek, Połczyn-Zdrój, Rąbino and Tychowo (Marshal's Office 2015). Particular types of complexes were assigned potential natural vegetation units, based on the results of own research in the study area. Classification and characteristics of the complexes were based on the paper by Drozd et al. (2010). What was assessed was biodiversity of the potential natural vegetation of forested areas and agricultural land, and the criterion was the trophy of the habitats. The indexation applied 5-class biodiversity scale (same as for geodiversity). The criterion for this assessment was based on the common view (including Falińska 2012) that species diversity increases with the habitat trophy. The lowest grade - 1st class (Table 2), was assigned to units correlated to oligotrophic habitats (poorest), while 
the highest (5th class) - with extremely eutrophic (richest). Data on the trophy of plant communities was obtained from the studies by Matuszkiewicz (2012) and Roo-Zielińska (2014).

Compact areas of settlement, industry and technical infrastructure and the like were omitted in the diagnosis of potential natural vegetation due to the strong transformation of the land surface. Their biodiversity, as well as of other areas of identified types of land cover, was rated on the basis of the concept of hemeroby presented by Sukopp (1972), except that the hemeroby degrees were specified by authors on the basis of syngenesis of plant associations forming the real vegetation. The assessment used a 5-class scale that reflected the level of vegetation anthropisation (Table 2). Syngenetic classification was given by Faliński (1969), whereas the data for syngenesis of plant communities was taken from Brzeg and Wojterska (2001).

The factor maps of biodiversity assessment, based on potential natural vegetation and hemeroby referring to the diversity of real vegetation, have the same resolution (i.e. $30 \times 30 \mathrm{~m}$ ) and spatial range as the geodiversity assessment map. To obtain total biodiversity maps, as in the case of geodiversity maps, the methods of combining factorial maps through the Weighted Sum tool in ArcGIS was used. Based on the expertise, a higher weight, i.e. 0.75 , was attributed to the assessment based on hemeroby and syngenesis of plant communities, while lower weight, i.e. 0.25 - was attributed to the assessment of potential natural vegetation diversity.

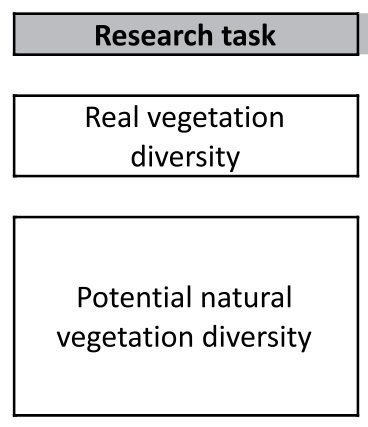

\begin{tabular}{|c|}
\hline Identification and \\
spatial range of the \\
potential natural \\
vegetation units in the \\
forest areas \\
\hline
\end{tabular}

Identification and spatial range of the potential natural vegetation units in the agricultural areas

Biodiversity assessment based on the potential natural vegetation units

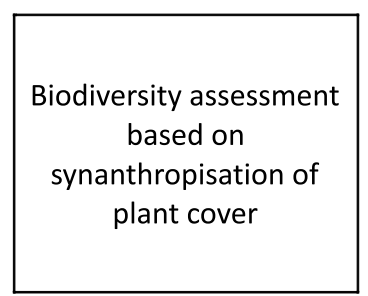

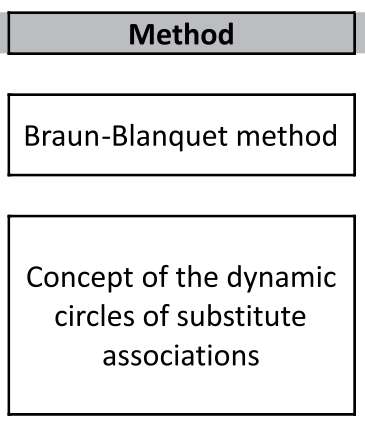
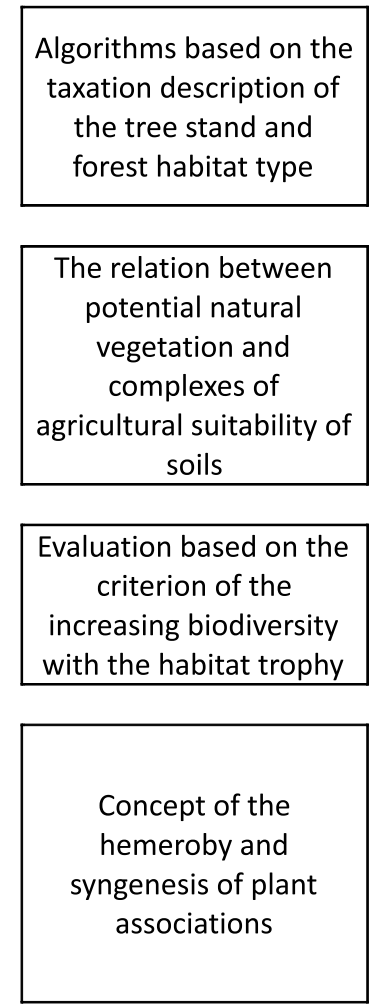
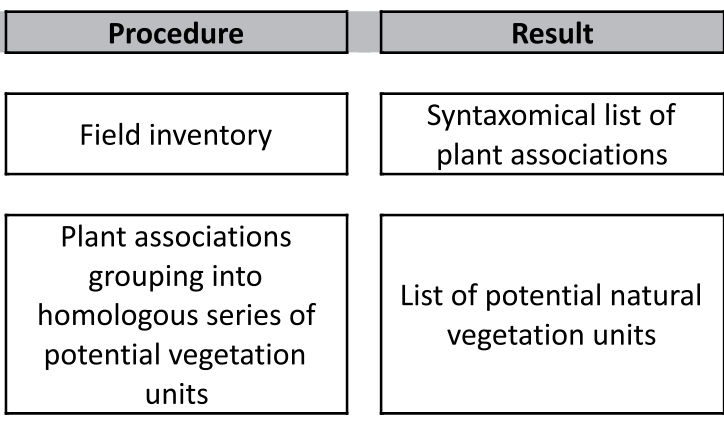
Analysis based on the data from the management plans for forest divisions
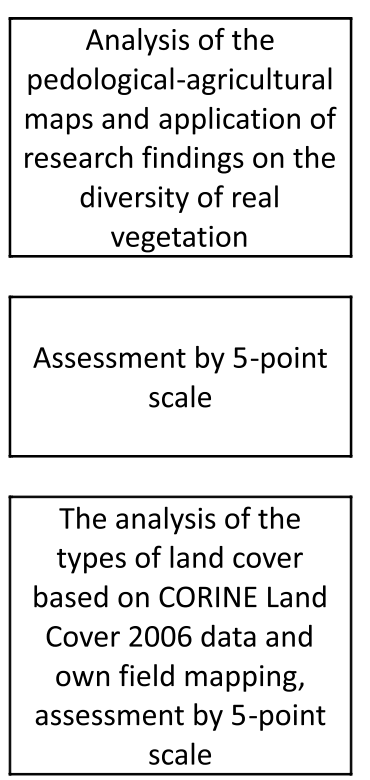

The potential natural vegetation map of the forest areas

The potential natural vegetation map of the agricultural areas

\section{Biodiversity factor map based on potential natural vegetation - Fig. 9}

$$
\begin{gathered}
\text { Biodiversity factor map } \\
\text { based on hemeroby } \\
\text { and vegetation origin } \\
\text { (synanthropisation of } \\
\text { plant cover) - } \\
\text { Fig. } 10
\end{gathered}
$$

Fig. 2. The Scope and methods of biodiversity assessment. 
Table 2. The criteria for the assessment of biodiversity values for particular factor maps.

\begin{tabular}{|c|c|c|c|c|c|}
\hline Criterion & \multicolumn{2}{|c|}{ Potential natural vegetation } & Habitats trophy & $\begin{array}{l}\text { Forest habitat } \\
\text { type }\end{array}$ & Biodiversity value \\
\hline \multirow{5}{*}{ 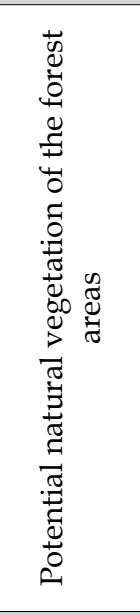 } & \multicolumn{2}{|c|}{ Vaccinio uliginosi-Pinetum, Leucobryo-Pinetum } & $\begin{array}{l}\text { dystrophic, } \\
\text { oligotrophic }\end{array}$ & Bb, Bśw & 1 - very low \\
\hline & \multicolumn{2}{|c|}{ Sphagno squarrosi-Alnetum } & $\begin{array}{l}\text { oligotrophic, } \\
\text { mesotrophic }\end{array}$ & $\mathrm{LMb}$ & $2-$ low \\
\hline & \multicolumn{2}{|c|}{$\begin{array}{l}\text { Vaccinio uliginosi-Betuletum, Deschampsio } \\
\text { flexuosae-Fagetum (= Fago-Quercetum p.p., Luzulo } \\
\text { pilosae-Fagetum), Calamagrostio arundinaceae- } \\
\text { Quercetum (=Fago-Quercetum p.p., Pino- } \\
\text { Quercetum p.p., Querco-Pinetum p.p.) } \\
\end{array}$} & mesotrophic & $\begin{array}{l}\text { BMb, Bmśw, } \\
\text { Bmw, LMw }\end{array}$ & 3 - medium \\
\hline & \multicolumn{2}{|c|}{$\begin{array}{l}\text { Ribeso nigri-Alnetum (=Carici elongatae-Alnetum), } \\
\text { Mercuriali-Fagetum, Melico-Fagetum, Stellario- } \\
\text { Carpinetum }\end{array}$} & $\begin{array}{l}\text { eutrophic, } \\
\text { mesotrophic }\end{array}$ & $\begin{array}{l}\text { Ol, LMśw, Lśw, } \\
\text { Lw }\end{array}$ & 4 - high \\
\hline & \multicolumn{2}{|c|}{$\begin{array}{l}\text { Salicetum albae (=Salici-Populetum p.p.), Fraxino- } \\
\text { Alnetum, Querco-Ulmetum minoris (=Ficario- } \\
\text { Ulmetum) }\end{array}$} & eutrophic & $\mathrm{Ll}, \mathrm{Olj}$ & 5 - very high \\
\hline Criterion & \multicolumn{2}{|c|}{ Complex of agricultural suitability of soils } & \multicolumn{2}{|c|}{ Potential natural vegetation } & Biodiversity value \\
\hline \multirow{5}{*}{ 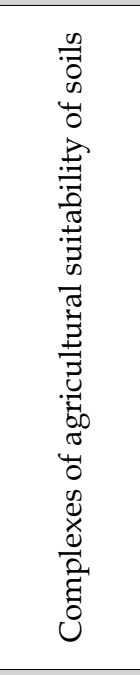 } & \multicolumn{2}{|c|}{ Tz. build-up areas } & \multicolumn{2}{|c|}{ None specified (metahemeroby) } & 1 - very low \\
\hline & \multicolumn{2}{|c|}{ 3z. poor and very poor grasslands } & \multicolumn{2}{|c|}{$\begin{array}{l}\text { Carici elongatae-Alnetum (=Ribeso } \\
\text { nigri-Alnetum) }\end{array}$} & $2-$ low \\
\hline & \multicolumn{2}{|c|}{$\begin{array}{l}\text { 6. weak rye, } 7 \text {. very weak rye, } 9 \text {. weak cereals- } \\
\text { fodder, RN. agricultural land designed } \\
\text { for afforestation }\end{array}$} & \multicolumn{2}{|c|}{$\begin{array}{l}\text { Deschampsio flexuosae-Fagetum } \\
\text { (=Fago-Quercetum p.p., Luzulo } \\
\text { pilosae-Fagetum), Calamagrostio } \\
\text { arundinaceae-Quercetum (=Fago- } \\
\text { Quercetum p.p., Pino-Quercetum p.p.) }\end{array}$} & 3 - medium \\
\hline & \multicolumn{2}{|c|}{$\begin{array}{l}\text { 2. wheat very good, } 3 \text {. wheat defective, } 4 \text {. rye } \\
\text { very good, } 5 \text {. rye good, } 8 \text {. good cereals-fodder, } \\
\text { 14. arable lands changed into grasslands, } 1 \mathrm{z} \text {. } \\
\text { very good and good grasslands, N. wasteland, } \\
\text { W. water, WN. water wasteland } \\
\end{array}$} & \multicolumn{2}{|c|}{$\begin{array}{l}\text { Stellario-Carpinetum, Melico-Fagetum, } \\
\text { waters }\end{array}$} & 4 - high \\
\hline & \multicolumn{2}{|c|}{ 2z. intermediate grasslands } & \multicolumn{2}{|c|}{$\begin{array}{l}\text { Salicetum albae (=Salici-Populetum } \\
\text { p.p.), Fraxino-Alnetum, Querco- } \\
\text { Ulmetum minoris (=Ficario-Ulmetum) }\end{array}$} & 5 - very high \\
\hline Criterion & Hemeroby & \multicolumn{3}{|c|}{ Degree of synatropisation of the natural vegetation } & Biodiversity value \\
\hline \multirow{5}{*}{ 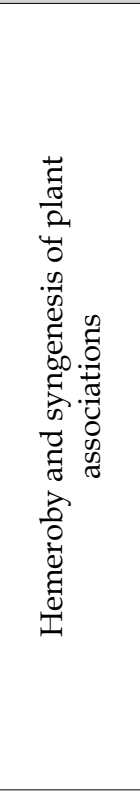 } & Metahemeroby & \multicolumn{3}{|c|}{$\begin{array}{l}\text { The strongest influence of anthropogenic factors; strong effect of } \\
\text { chemical substances in the air, water and soil; almost complete } \\
\text { destruction of biological life; areal dominance of synanthropic } \\
\text { plant associations of unspecified syntaxonomy }\end{array}$} & 1 - very low \\
\hline & Polyhemeroby & \multicolumn{3}{|c|}{$\begin{array}{l}\text { Very strong influence of different anthropogenic factors causing } \\
\text { very high changes in substrate; areal dominance of specialized } \\
\text { synanthropic ruderal plant associations }\end{array}$} & $2-$ low \\
\hline & Euhemeroby & \multicolumn{3}{|c|}{$\begin{array}{l}\text { Strong and continuous influence of anthropogenic factors } \\
\text { causing distinct changes in substrate; areal dominance of } \\
\text { synanthropic segetal and ruderal, as well as xenospontaneous } \\
\text { plant associations }\end{array}$} & 3 - medium \\
\hline & Mezohemeroby & \multicolumn{3}{|c|}{$\begin{array}{l}\text { Weak or only periodically active anthropogenic factors; small } \\
\text { changes in substrate of reversible character; areal dominance } \\
\text { of autogenic natural and anthropogenic seminatural plant } \\
\text { associations }\end{array}$} & 4 - high \\
\hline & Oligohemeroby & \multicolumn{3}{|c|}{$\begin{array}{l}\text { Small influence of human that does not cause changes in } \\
\text { substrate; real vegetation corresponds to potential natural } \\
\text { vegetation; areal dominance of autogenic natural plant } \\
\text { associations }\end{array}$} & 5 - very high \\
\hline
\end{tabular}




\section{Geodiversity and biodiversity assessments}

The collected field and literature data, both analogue and digital, allowed for assessing geodiversity and biodiversity of Dębnica River catchment. A total of seven factor maps were obtained, i.e. five maps for the diversity of abiotic elements (Figs 3-7), and two for the diversity of biotic elements (Figs 9-10), which became the basis for the creation of total geodiversity (Fig. 8) and biodiversity (Fig. 11) maps.

\section{Geodiversity map}

The first factor map - a map of lithological diversity (Fig. 3), was based on discrete qualitative data as a result of aggregation of 19 classes of sediment lithology. The analysis excluded poorly studied bottom sediments of larger water bodies ('no data' in the legend). The boundaries of the classified polygons in the form of patches are clearly indicated on the map design. More than half of the study area was classified as lithologically moderately diverse (Table 3). It includes mainly a wide valley of Dębnica River, developed in the sands and gravels of fluvioglacial origin, and river valleys of lower order, as well as forms generated in the area of areal deglaciation built of sand and gravel deposits. A larger part of the catchment is taken by areas of high and very high lithological variety. These are the areas least sensitive to mechanical denudation that is, much bigger resistance to soil and gully erosion, which transposes into preservation of the relief rhythm, and thus slope shapes and gradient. What should be distinguished here are frontal moraines hills, mainly built of gravels and glacial tills, part of the Pomeranian Ridge. The smallest lithological diversity is associated primarily with large flat bottomed depressions filled with silt mineral-organic deposits and/or biogenic deposits, e.g. peat.

The map of relative heights (Fig. 4) is the result of processing a digital elevation model of the investigated area, and thus it is continuous quantitative data. In terms of the local heights Dębnica River catchment diversity is relatively minor (Table 3), which clearly reflects the morphology of the foreground and background of the frontal moraine hills of the postglacial genesis. Over $70 \%$ of the catchment area shows very low and low diversity, indicating heights up to $5 \mathrm{~m}$. The highest (class 4 and 5) differences in relative heights comprise about $10 \%$ of the area. These are mainly the edges of the moraine plateaus and elevated valley slopes, including gorge sections of Dębnica River, as well as hillslopes of frontal moraines and kame hills. The map of relative height diversity highly correlates $(r=0.976)$ with a slope map of Dębnica River catchment.

The landform fragmentation diversity map (Fig. 5 ) is the result of processing continuous quantitative data from a digital elevation model. As a result of the semi-automatic and expert classification, the map is characterised by an irregular mosaic of landforms, similar to the lithological diversity (Fig. 3). The map mainly highlighted Weichselian postglacial forms characteristic for the study area, such as extensive ice-marginal valley (Pol. pradolina), deeply incised erosion and erosion-denudation valleys, frontal moraine hills, kame plateaus, undulating moraine plateaus, and even a gorge of Dębnica

Table 3. The percentage of diversified areas in terms of geodiversity values based on: lithological diversity (A), relative height diversity (B), landform fragmentation diversity (C), hydrographical elements diversity (D), mesoclimatic diversity $(E)$ and total geodiversity $(A+B+C+D+E)$.

\begin{tabular}{|c|c|c|c|c|c|c|}
\hline \multirow{4}{*}{$\begin{array}{c}\text { Geodiversity } \\
\text { value }\end{array}$} & \multicolumn{5}{|c|}{ Geodiversity factor map } & \multirow[b]{2}{*}{$\begin{array}{l}\text { Map of total } \\
\text { geodiversity }\end{array}$} \\
\hline & $\begin{array}{l}\text { based on } \\
\text { lithological } \\
\text { diversity }\end{array}$ & $\begin{array}{l}\text { based on } \\
\text { relative height } \\
\text { diversity }\end{array}$ & $\begin{array}{l}\text { based on } \\
\text { landform } \\
\text { fragmentation } \\
\text { diversity }\end{array}$ & $\begin{array}{c}\text { based on } \\
\text { hydrograph- } \\
\text { ical elements } \\
\text { diversity }\end{array}$ & $\begin{array}{c}\text { based on } \\
\text { mesoclimatic } \\
\text { diversity }\end{array}$ & \\
\hline & (A) & (B) & (C) & (D) & (E) & $(A+B+C+D+E)$ \\
\hline & \multicolumn{6}{|c|}{ [\%] } \\
\hline 1 - very low & 6.4 & 33.5 & 28.2 & 16.5 & 10.2 & 19.5 \\
\hline $2-$ low & 1.2 & 36.6 & 37.2 & 15.9 & 36.4 & 31.9 \\
\hline 3 - medium & 55.4 & 19.2 & 18.3 & 8.3 & 27.8 & 24.8 \\
\hline 4 - high & 14.6 & 8.5 & 6.8 & 0.9 & 18.5 & 14.9 \\
\hline 5 - very high & 21.8 & 2.2 & 9.5 & 0.2 & 7.2 & 8.9 \\
\hline
\end{tabular}




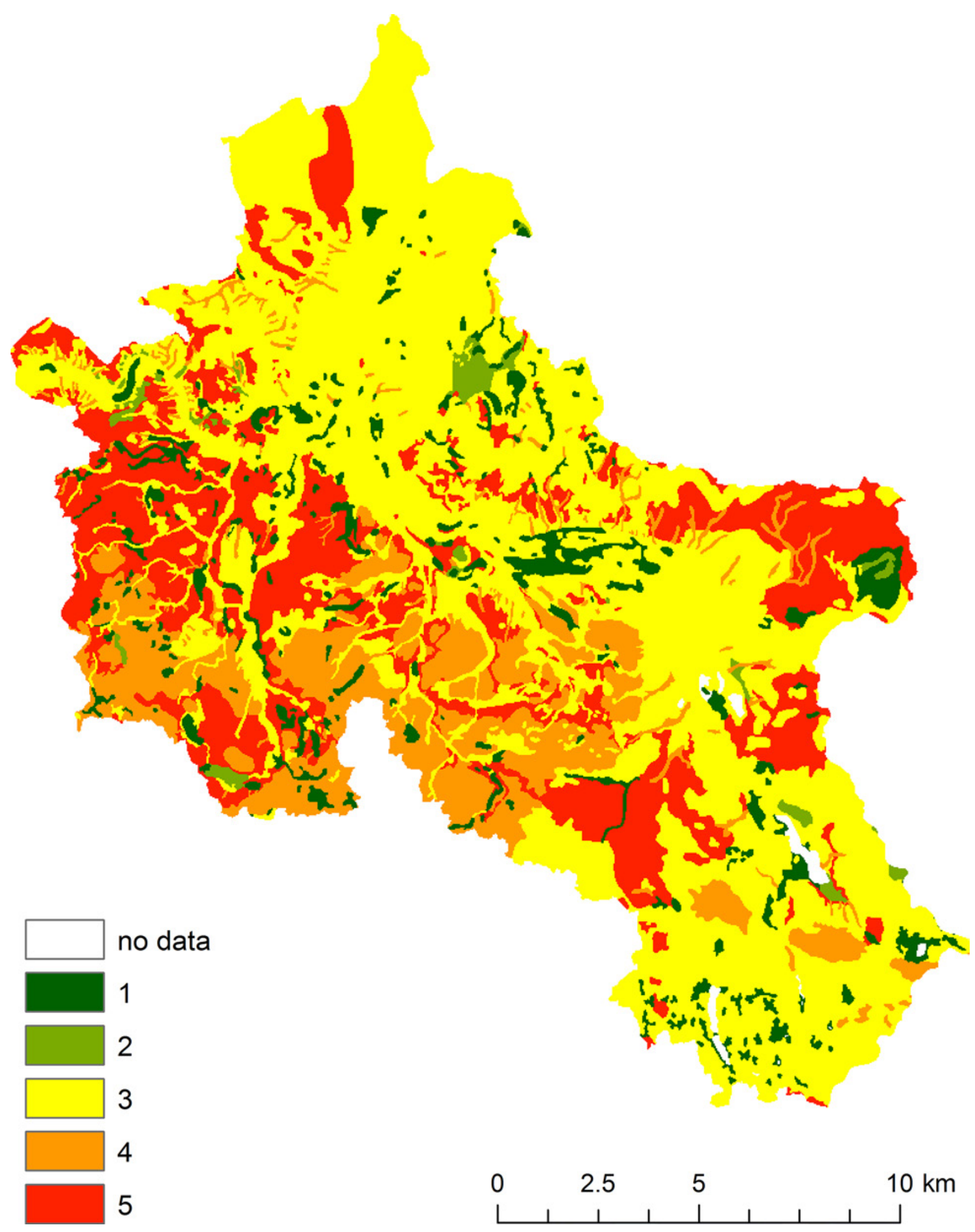

Fig. 3. Factor map of the lithological diversity.

Diversity classes: 1 - very low, 2 - low, 3 - medium, 4 - high, 5 - very high. 


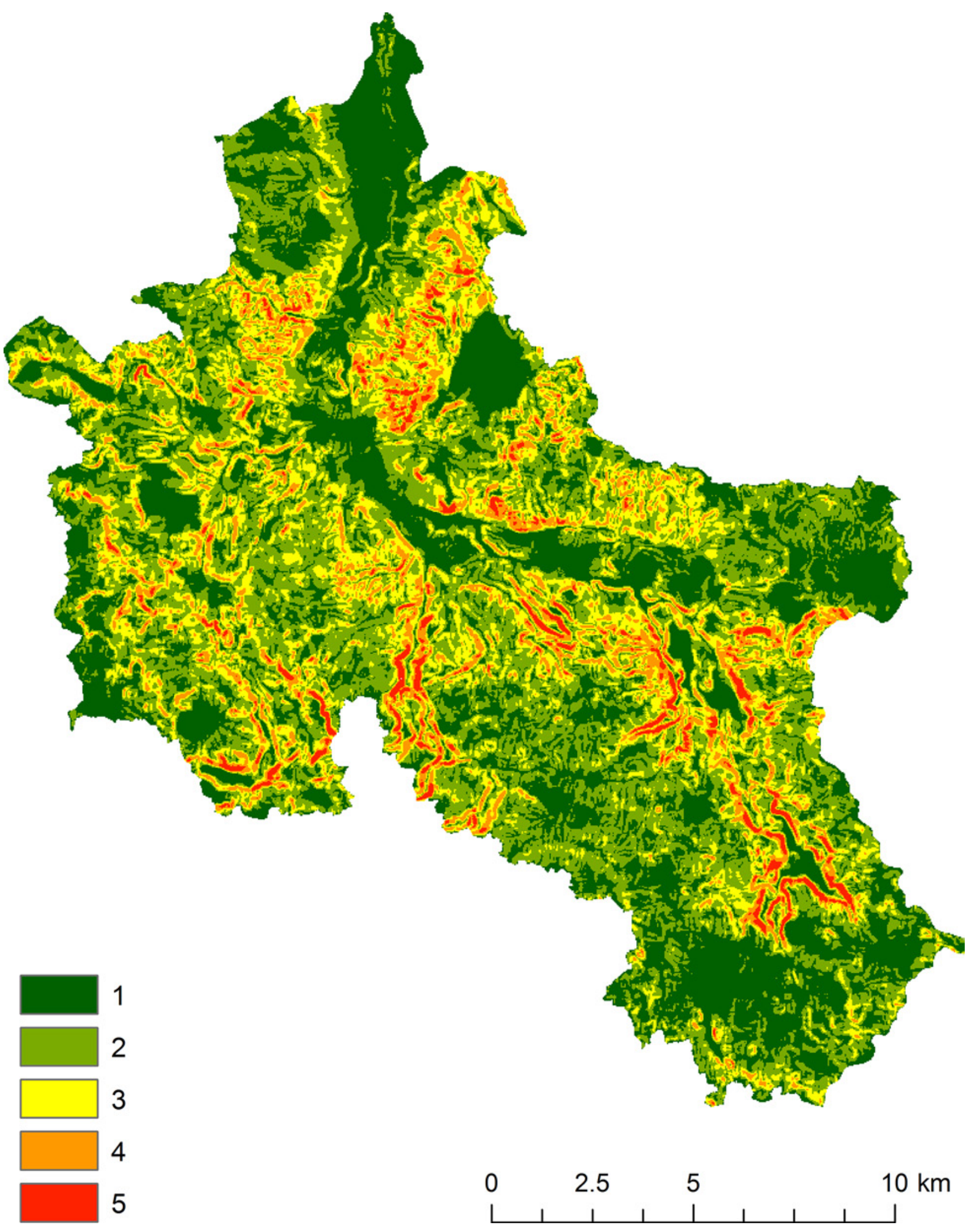

Fig. 4. Factor map of the relative height diversity.

Diversity classes: 1 - very low, 2 - low, 3 - medium, 4 - high, 5 - very high. 


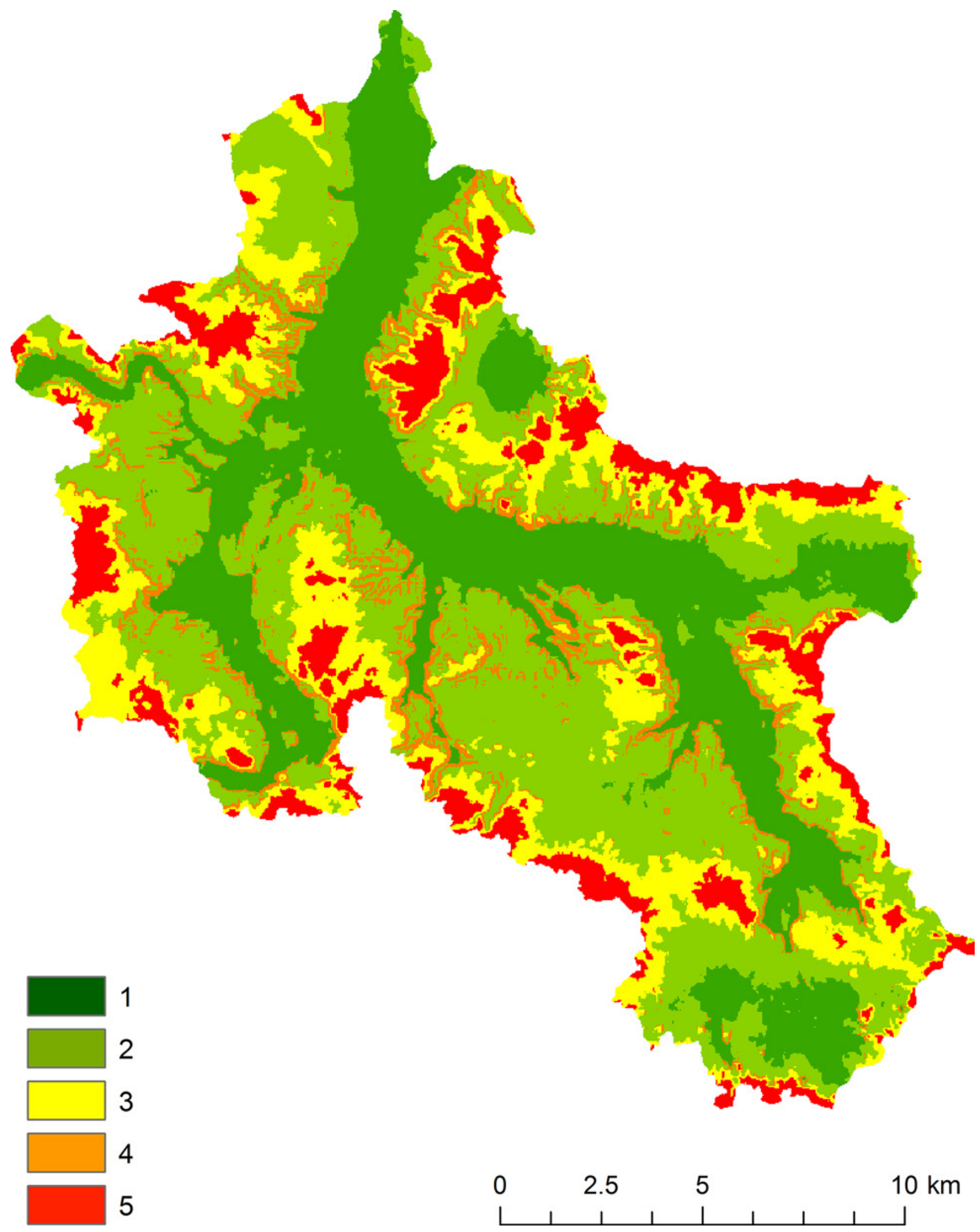

Fig. 5. Factor map of the landform fragmentation diversity.

Diversity classes: 1 - very low, 2 - low, 3 - medium, 4 - high, 5 - very high. 


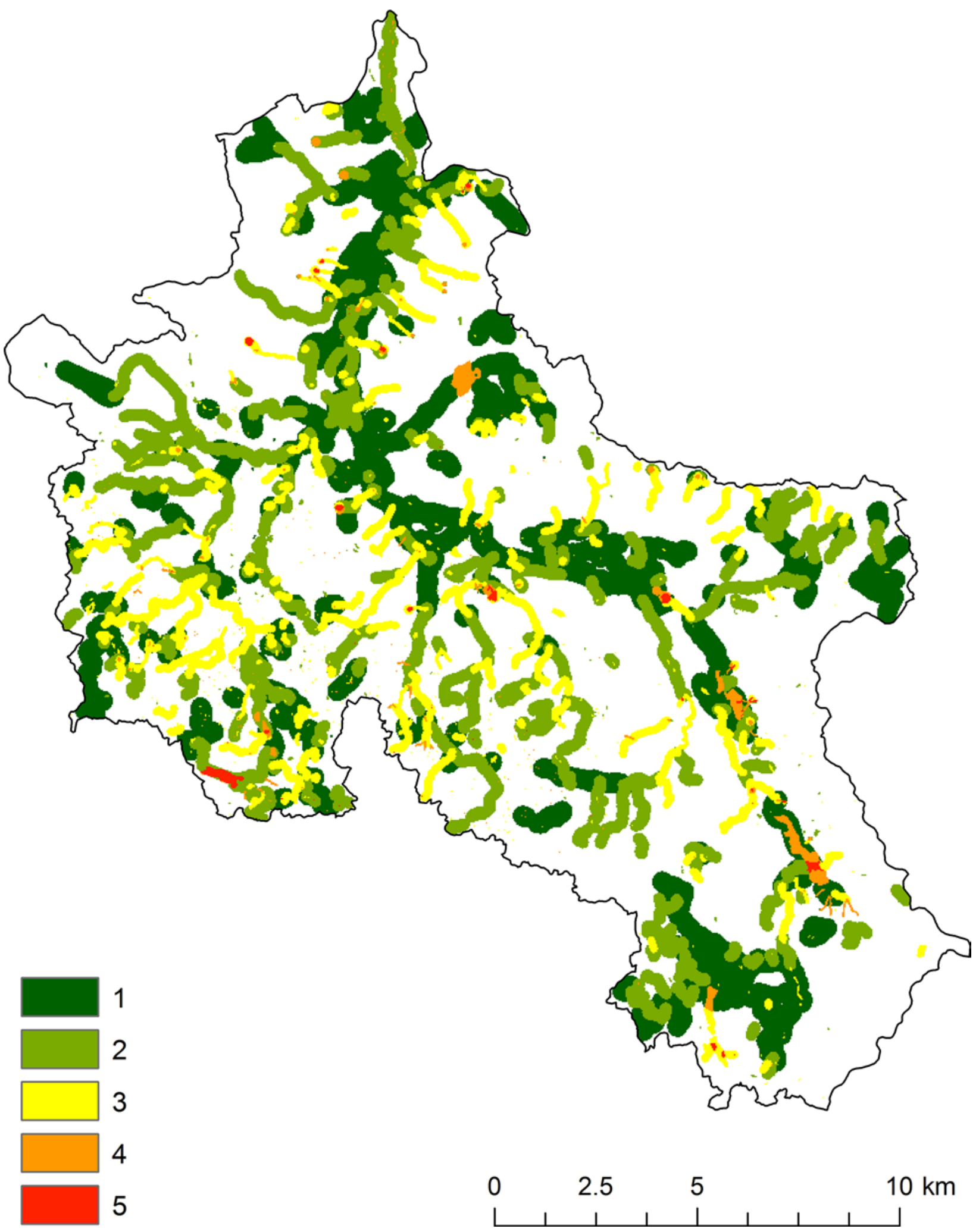

Fig. 6. Factor map of the hydrographical elements diversity.

Diversity classes: 1 - very low, 2 - low, 3 - medium, 4 - high, 5 - very high. 


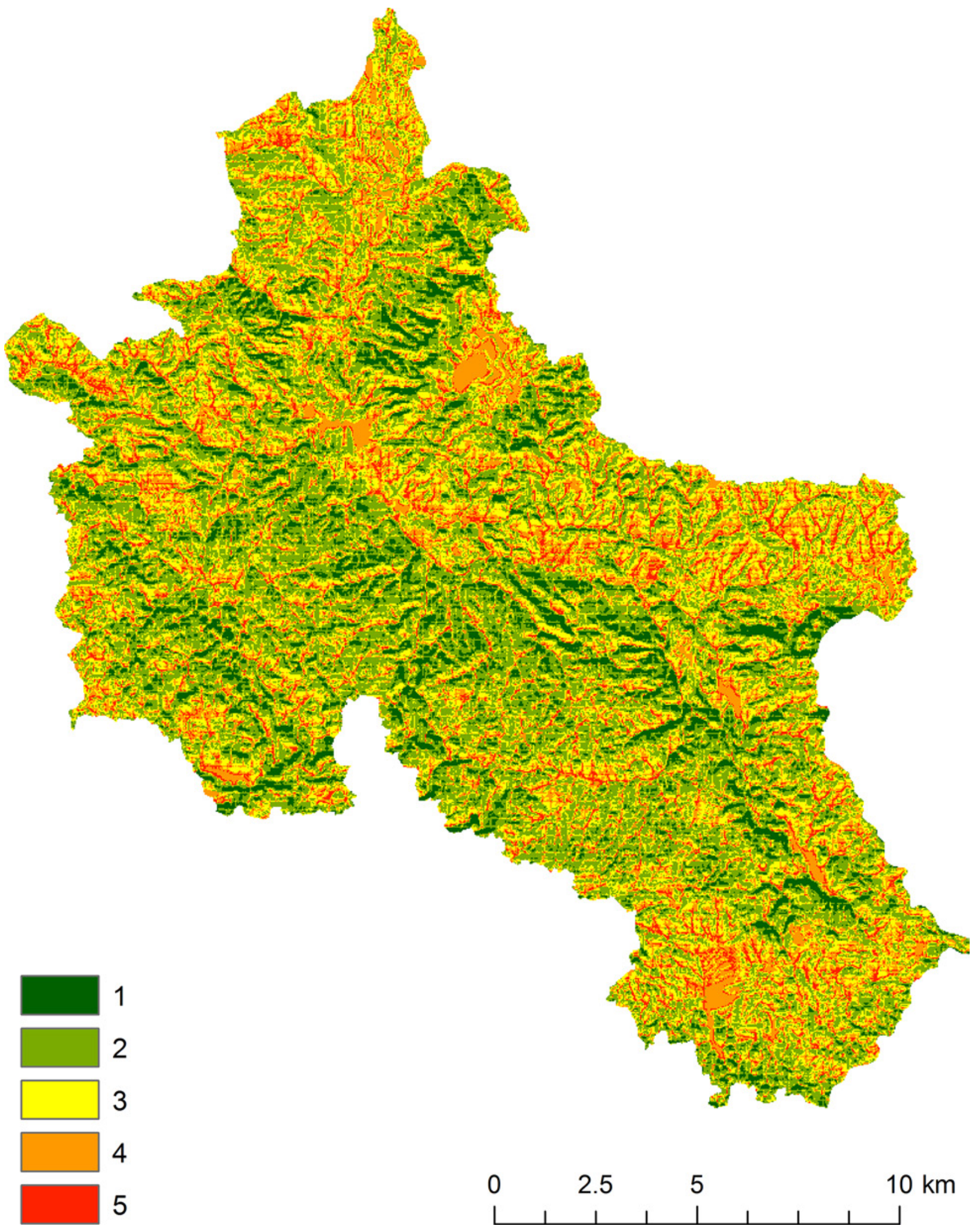

Fig. 7. Factor map of the mesoclimatic diversity.

Diversity classes: 1 - very low, 2 - low, 3 - medium, 4 - high, 5 - very high. 


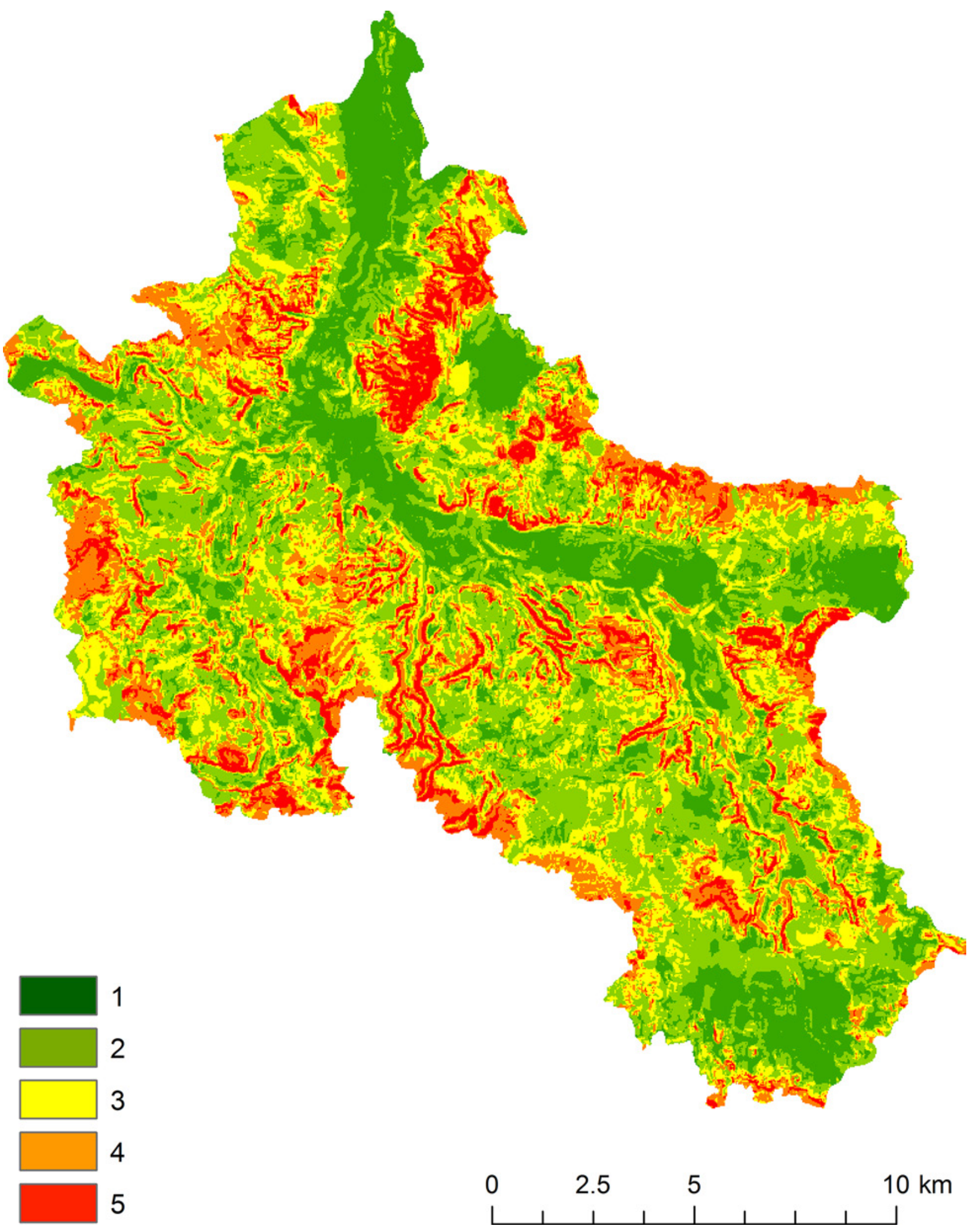

Fig. 8. Total geodiversity map of Dębnica River catchment.

Geodiversity classes: 1 - very low, 2 - low, 3 - medium, 4 - high, 5 - very high. 


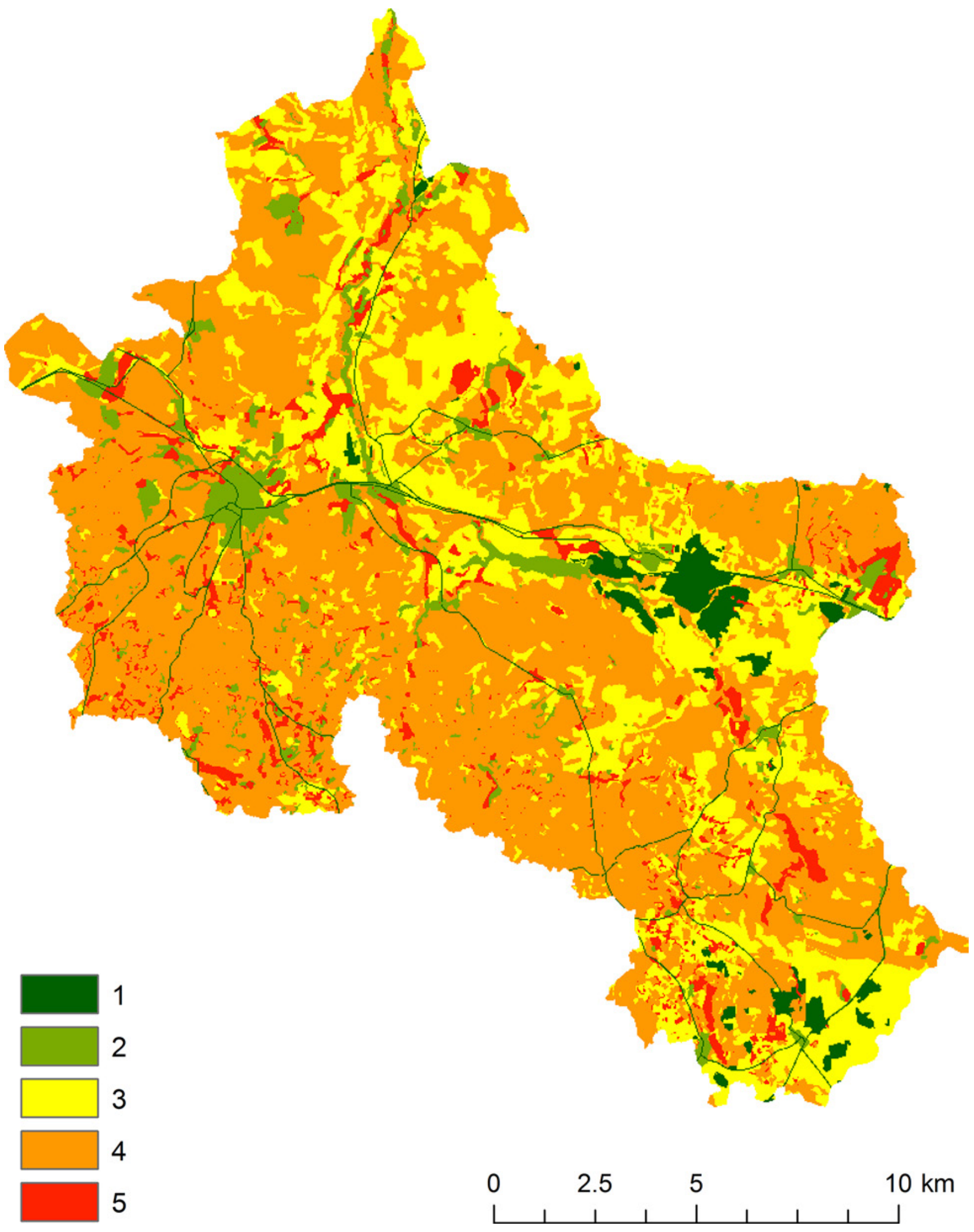

Fig. 9. Factor map of the biodiversity based on potential natural vegetation. Diversity classes: 1 - very low, 2 - low, 3 - medium, 4 - high, 5 - very high. 


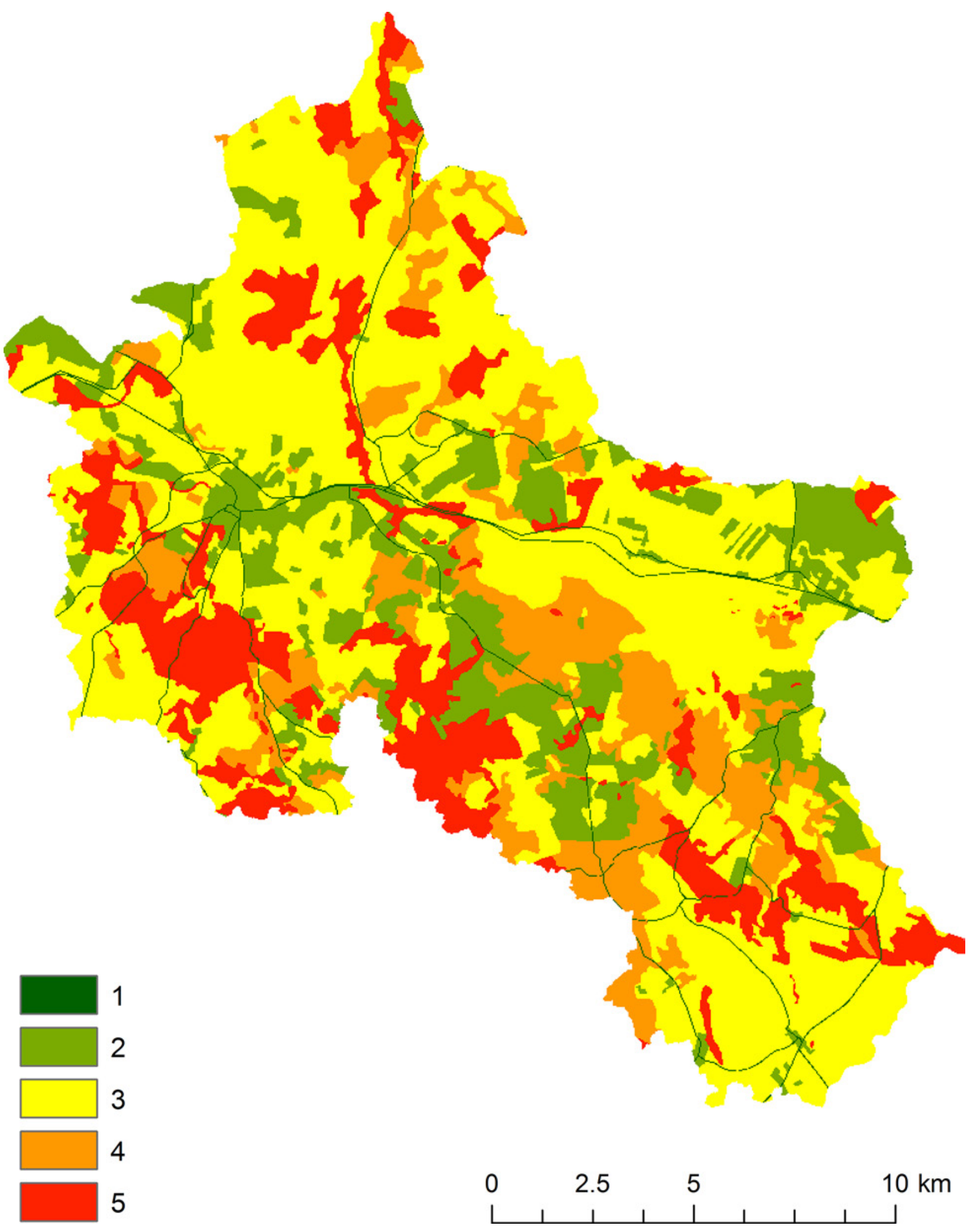

Fig. 10. Factor map based on hemeroby and vegetation origin (synanthropisation of plant cover). Diversity classes: 1 - very low, 2 - low, 3 - medium, 4 - high, 5 - very high. 


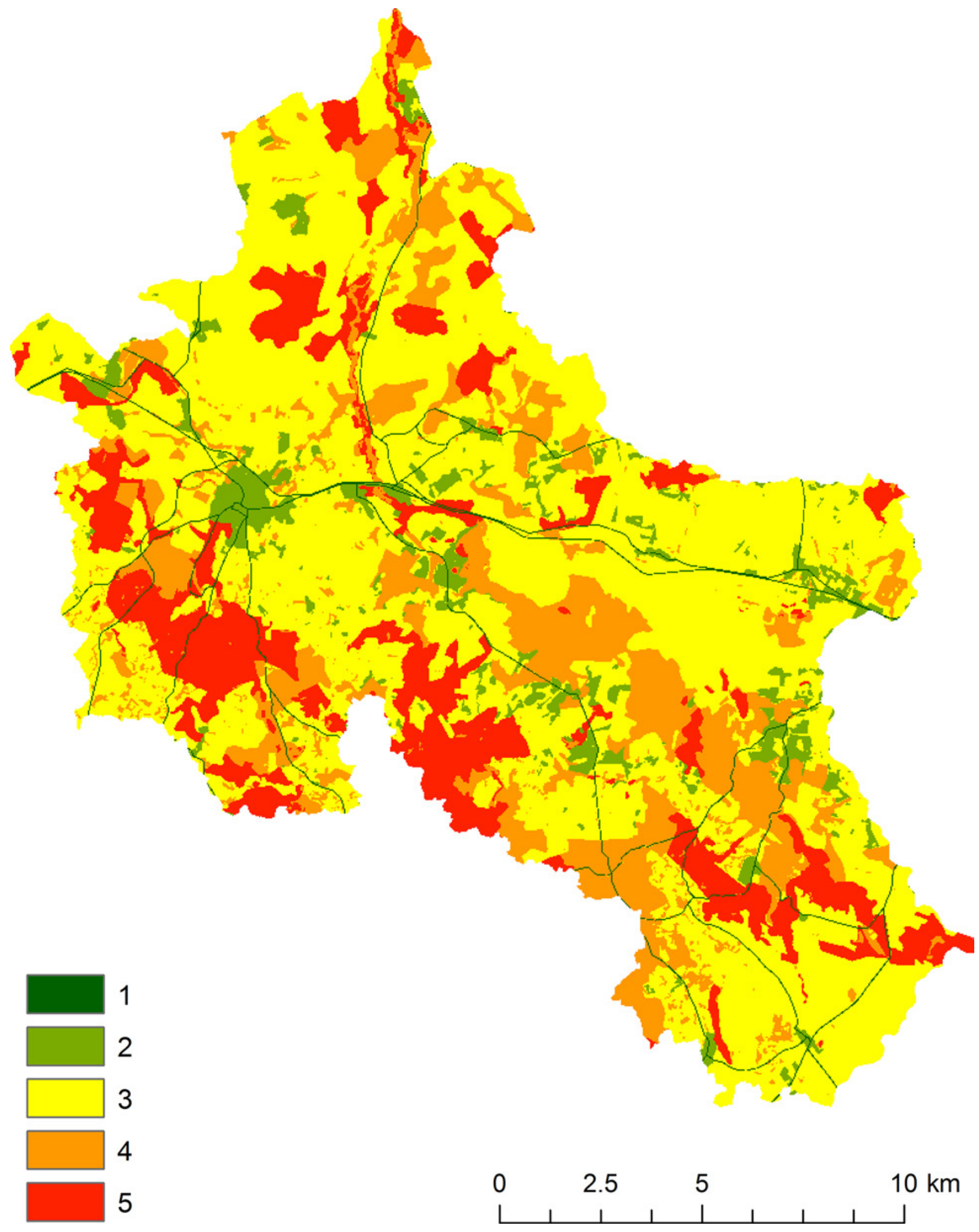

Fig. 11. Total biodiversity map of Dębnica River catchment.

Biodiversity classes: 1 - very low, 2 - low, 3 - medium, 4 - high, 5 - very high. 
River in the southern part of the catchment. What dominates is low and very low diversity (about 65\%, Table 3), including primarily the middle reaches of the wide valley of the main river. The largest diversity of landform fragmentation occurs along the morphological axis of the Pomeranian Ridge built of sequences of moraine hills of the recession stages of the Pomeranian phase in the middle part of the catchment.

The diversity of hydrographical elements relates to $41.8 \%$ of the catchment (Fig. 6). Such spatial participation of hydrographical elements is due to the youth and weak development of the river network in the postglacial area and - locally - small share of lakes in hydrographic network. Very low, low and medium degree of diversity dominates $(97 \%$, Table 3), mainly due to the river network. The highest values occur most frequently at single places: in the groundwater zones and upper reaches of rivers, and in patches: around Lake Kłokowskie and Lake Dębno. The areas with locally higher diversity emphasise the importance of the groundwater outflows in the development of a river system (Mazurek 2010).

The last of the factor maps, a map of mesoclimatic diversity (Fig. 7), is a map of continuous data. Its mosaicism is very large. The largest percentage of the area is a zone of low ( $2^{\text {nd }}$ class $\left.-36.4 \%\right)$ and medium ( $3^{\text {rd }}$ class $-27.8 \%$ ) mesoclimatic diversity (Table 3). In Dębnica River catchment 7\% of the area comprises the areas of the scattered distribution, which may be described as mesoclimatically diverse. These are mainly steep slopes of valleys and subglacial channels occupied by lakes of southern and south-western exposure that receive the greatest amount of solar radiation.

Figure 8 shows the total geodiversity map of Dębnica River catchment. To a large extent it refers to the factor maps: of a landform fragmentation diversity (Fig. 5) and of relative heights (Fig. 4). This is primarily a result of glacial genesis of the relief and its denudation-fluvial transformation in the Holocene, as well as fragmented relief and the present-day differences in elevation, slope and exposure. Therefore, these two factor maps were assigned higher weights, i.e. 0.36 and 0.35 , respectively.

Very low (19.5\%) and low geodiversity (31.9\%) characterises more than half of the catchment area (Table 3). It is mostly a vast valley of the mouth and middle reaches of Dębnica, and a drainage area around Lake Radoniowieckie. This group also includes anthropogenically changed areas with bigger towns such as Połczyn-Zdrój, Barwice and Polne (see Fig. 1). Very high fragmentation and significant participation show the areas classified as areas of medium geodiversity (24.8\%). High (14.9\%) and very high $(8.9 \%)$ geodiversity is mainly associated with the typical postglacial relief forms of the marginal zone of the Pomeranian phase of the Weichselian glaciation.

The biggest patch of high geodiversity in the catchment are Skowrończe Hills, adjacent to the lower reach of Dębnica River valley from the east. It is a kame plateau, approx. $9 \mathrm{~km}$ long and 2-3 km wide, built of fluvioglacial and lacustrine sandy-gravel deposits (Dobracka 2009). This area has highly varied topography with plenty culminations, erosion-denudation valleys dissecting the hillslopes and headwater alcoves, which are an effect of groundwater seepage erosion (Mazurek, Paluszkiewicz 2013). The area of high and very high geodiversity are also Buślarskie Hills located on the west side of Dębnica River valley. This is an area of undulating plateau elevations built of sandy sediments. The slopes of the plateau are scattered with numerous erosion-denudation valleys (Paluszkiewicz 2013). High geodiversity is also found at a terminal moraine hill of Piaskowa Hill from the east and Brusińskie Hills from the west, dissected by a gorge of Dębnica River valley. The height difference at this gorge section reaches $40 \mathrm{~m}$, and the slope of the riverbed of up to $23 \%$ is conducive to severe bottom erosion. High geodiversity values were assigned to the moraine hills, such as Wiatraczna Hill (203 m a.s.l.), Popielewskie Hills and kame hills, such as Kołacza Hill (160 m a.s.l.), and the moraine hills constituting the watershed.

In conclusion, the adopted procedure for assessing geodiversity provides very good results that reflect an extremely genetically varied Quaternary postglacial landscape with the Holocene denudative transformation. The areas with the highest geodiversity value, due to their uniqueness are often legally protected, such as Drawsko Landscape Park and the Dębnica River Gorge Nature Reserve. It should be recognised that this method can be used for the delimitation of abiotically diversified areas for geoconservation and geoheritage as well as conduct relevant forms of sustainable development. 


\section{Biodiversity map}

Maps that evaluate biodiversity based on potential natural vegetation (Fig. 9), hemeroby and syngenesis of plant associations (Fig. 10) differ one from the other substantially. These differences are visible both in the spatial distribution of areas differing in natural values and their shape and size.

Based on field mapping real vegetation of Dębnica River catchment is differentiated into 165 plant associations representing 23 classes, 31 orders and 52 alliances of the phytosociological syntaxonomy. The majority of associations are of natural syngenesis (108 associations, $65 \%$ ). The rest belong to anthropogenic syntaxa, including: seminatural (16 associations, $10 \%$ ), synanthropic ruderal (22 associations, 13\%), synanthropic segetal (13 associations, $8 \%$ ) and xenospontaneous ( 6 associations, $4 \%$ ). The majority of associations belong to common (54 associations, $33 \%$ ) or frequent (74 associations, $45 \%$ ) in the West Pomerania region, while the contribution of very rare (5 associations, $3 \%$ ) and rare (32 associations, $20 \%$ ) associations is low. Numerous associations are ranked as vulnerable on the regional scale (34 associations, 21\%) and some as endangered (11 associations, $7 \%$ ). As a result of the field mapping 12 units of potential natural vegetation were identified: swamp alder forest Carici elongatae-Alnetum, peatbog birch forest Vaccinio uliginosi-Betuletum, peatbog pine forest Vaccinio uliginosi-Pinetum, willow carr Salicetum albae, ash-alder carr Fraxino-Alnetum, oak-elm carr Querco-Ulmetum minoris, oak-hornbeam forest Stellario-Carpinetum, springfen beech forest Mercuriali-Fagetum, lowland forb-rich beech forest Melico-Fagetum, lowland acidophilous beech forest Deschampsio flexuosae-Fagetum, acidophilous oak forest Calamagrostio arundinaceae-Quercetum and typical pine forest Leucobryo-Pinetum. Units were classified according to the methodology of Matuszkiewicz et al. (1995). The spatial extent of these units was recognized.

The biodiversity map based on potential natural vegetation (Fig. 8) shows that areas with high biodiversity decidedly prevail (Table 4 ). They form extensive matrixes containing patches of high or medium biodiversity. These patches are dispersed on the moraine hills of Pomeranian Ridge, situated in the south-west and south-central part of the catchment. In the whole catchment, along its SENW axis, the areal contribution of the patchwork of high and medium biodiversity areas is more or less balanced. Patches with high biodiversity are situated along Dębnica River valley, which accentuates the axial layout of vegetation.

On the biodiversity map showing evaluation based on hemeroby and syngenesis of plant associations (Fig. 9), the patches of the highest value are clearly concentrated in the south, mostly forested part of the catchment, where they occupy large and compact areas bordered by the areas of high or medium biodiversity. In the northern part of the catchment, dominated by agricultural landscapes of ground moraine, areas with medium biodiversity decidedly prevail.

The total biodiversity assessment based on both mentioned maps provided a similar outcome (Fig. 10). However, in this case, the contribution of areas with low biodiversity is distinctly smaller, while areas of very high and high biodiversity refer to the occurrence of areas with very high and high degree of hemeroby. This results from the assigned weights, which for the biodiversity map based on hemeroby and vegetation origin was 0.75 , while in case of the map based on potential natural vegetation -0.25 .

Table 4 . The percentage of diversified areas in terms of biodiversity values based on: potential natural vegetation (A), hemeroby and plant association syngenesis (B) and total biodiversity $(A+B)$.

\begin{tabular}{|c|c|c|c|}
\hline \multirow{3}{*}{ Biodiversity value } & \multicolumn{2}{|c|}{ Biodiversity factor map } & \multirow[b]{2}{*}{$\begin{array}{l}\text { Map of total biodiversity } \\
\qquad(\mathrm{A}+\mathrm{B})\end{array}$} \\
\hline & $\begin{array}{l}\text { based on potential natural } \\
\text { vegetation } \\
\text { (A) }\end{array}$ & $\begin{array}{l}\text { based on hemeroby and plant } \\
\text { association syngenesis } \\
\text { (B) }\end{array}$ & \\
\hline & \multicolumn{3}{|c|}{ [\%] } \\
\hline 1 - very low & 4.0 & 1.6 & 1.6 \\
\hline $2-$ low & 5.2 & 15.8 & 5.4 \\
\hline 3 - medium & 26.0 & 51.5 & 58.8 \\
\hline 4 - high & 59.6 & 14.9 & 18.7 \\
\hline 5 - very high & 5.3 & 16.2 & 15.5 \\
\hline
\end{tabular}




\section{Conclusions}

In this paper an attempt was primarily made to propose a new unified procedure for geodiversity and biodiversity assessments through factor maps of the natural environment components aggregation, with the use of multi criteria evaluation. The adopted method achieved good results that reflected an extremely genetically varied postglacial landscape with the Holocene remodelling. The obtained results were reviewed during the field exploration with positive results, which afforded a basis to conclude that the methodology used was correct and could be applied for other similar areas. Maps produced in accordance with given procedure may find a wide range of applications.

Field mapping set the opportunity for a very accurate clarification of the source data that allows evaluation of the abiotic and biotic natural environment components in detail. The resolution of geospatial data $(30 \mathrm{~m})$ permits the use of the created maps primarily for the analysis of landscape evolution, planning purposes to prepare projects for local area development or landscape-ecological plans.

The comparison of the percentage of an area of particular classes of geodiversity and biodiversity, has been presented on a single graph (Fig. 12) and gives the possibility to conclude that the classes of biodiversity have a distribution close to normal (Gaussian), while classes of geodiversity have a right-skewed (positive skewness) distribution.
While the distribution of biodiversity classes can be regarded as an appropriate for natural environmental phenomena, in the case of geodiversity classes an interpretation of that right-skewed distribution remains for further investigation. Referring to Zwoliński's concept of geosuccession (2007) it can be insinuated that a right-skewed distribution may signal the advanced stages of geosuccession in the landscape development. However, that statement requires further verification and confirmation in areas morphogenetically and morpho-chronologically different.

Maps of geodiversity and biodiversity produced in accordance with given procedure may prove to be helpful in determining the directions for management of lands valuable from the nature point of view, as well as delimitation of new forms of nature preservation. The procedure may also become an outstanding and universal tool to facilitate proper management of natural environment resources for the purpose of geopark establishment as well as tourism and especially geotourism. Hopefully, presented research results are going to be used in the development of the spatial-functional organisation in the design of the Postglacial Land of Drawa \& Dębnica Geopark (Pol. Polodowcowa Kraina Drawy $i$ Dębnicy) which partially covers the area of research.

On the basis of the factor and total maps of geodiversity and biodiversity, it is also possible to present actions preventing, restricting (minimizing) or offsetting the negative impact on the natural

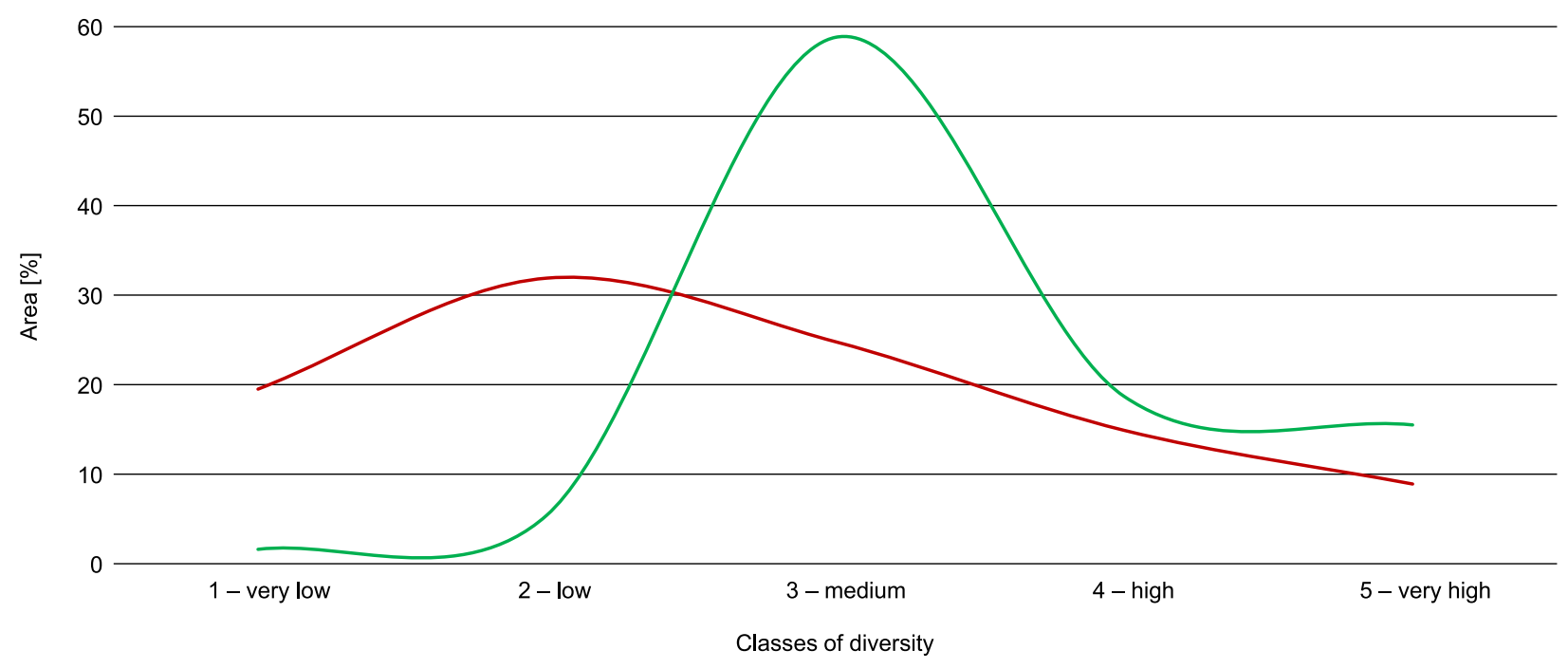

- Classes of total geodiversity

_ Classes of total biodiversity

Fig. 12. Ecodiversity pattern between geodiversity and biodiversity for Dębnica River catchment (cf. Table 1 and 2). 
environment. Particularly in case of the reports on environmental impact assessment of projects they might be indispensable for an appropriate indication of the best project variant that would be the most advantageous for the natural environment and prevent the most diversified areas from permanent degradation.

As underlined by Hjort et al. (2015) the basic assumption of the biodiversity protection is simultaneous preservation of its abiotic environment. The assessments of geodiversity and biodiversity can be indispensable for creating identification cards and landscape audit (Solon et al. 2014) and for developing the national list of protected landscapes based on the guidelines of the European Landscape Convention (Marcinek et al. 2009) and the Landscape Act (Ustawa krajobrazowa... 2015), as well as when choosing landscapes for the Red Book of the Landscape of Poland (BaranowskaJanota et al. 2007).

Maps of geodiversity and biodiversity show hotspots of ecosystem services from all sections distinguished in the hierarchical classification CICES_V.4.3: a) provisioning, b) regulation and maintenance, and c) cultural (Borysiak et al. 2014, Science for Environment Policy 2015). Hotspots are the areas that have been highly valorised in terms of geodiversity and biodiversity. Their identification allows for the implementation of the policy of sustainable management of geographical environment.

\section{Acknowledgments}

The authors would like to express gratitude for sharing the source data to the following: Regional Directorate of State Forests in Szczecinek for providing digital maps of forests and Westpomeranian Marshal's Office for maps of agriculture and soils. We are also extremely thankful to Adam Mickiewicz's University for financial support of the research.

\section{Author contributions}

The authors admit to divide the following percentage contribution: Alicja Najwer - 55\%, Joanna Gudowicz - 10\%, Janina Borysiak - 10\%, Małgorzata Mazurek - 10\% and Zbigniew Zwoliński - 15\%.

\section{References}

Alexandrowicz Z., Margielewski W., 2010. Impact of mass movements on geo-and biodiversity in the Polish Outer (Flysch) Carpathians. Geomorphology 123: 290-304.

Baranowska-Janota, M. 2007. Turystyka w planach zagospodarowania przestrzennego i planie ochrony Tatrzańskiego Parku Narodowego. In: Pociask-Karteczka J., Matuszyk A. and Skawiński P. (eds.), Stan i perspektywy rozwoju turystyki w Tatrzańskim Parku Narodowym, Studia i monografie, Kraków-Zakopane: Akademia Wychowania Fizycznego w Krakowie, Tatrzański Park Narodowy, p. 55.

Barthlott W., Biedinger N., Braun G., Feig F., Kier G., Mutke J., 1999. Terminological and methodological aspects of the mapping and analysis of the global biodiversity. Acta Botanica Fennica 162: 103-110.

Bartkowski T., 1977. Metody badań geografii fizycznej. Państwowe Wydawnictwo Naukowe. Warszawa-Poznań.

Beven K.J., Kirkby, M.J., 1979. A physically-based variable contributing area model of basin hydrology. Hydrology Science Bulletin 24(1): 43-69.

Borysiak J., 2015. The benefits of organic farming to spontaneous vascular flora biodiversity; West Pomerania (Poland). Acta Agrobotanica 68(3): 217-232.

Borysiak J., Mazurek M., Zwoliński Z., 2014. Land cover and ecosystem services changes in agricultural landscapes of the Dębnica River catchment (West Pomerania, Poland). Ekonomia i Środowisko 4(51): 205-220.

Bródka S., 2010. Etapy oceny środowiska przyrodniczego w ujęciu praktycznym. In: Bródka S. (ed.), Praktyczne aspekty ocen środowiska przyrodniczego. Bogucki Wyd. Nauk., Poznań.

Brzeg A., Wojterska M., 2001. Zespoły roślinne Wielkopolski, ich stan poznania i zagrożenie. In: Wojterska M. (ed.), Szata roślinna Wielkopolski i Pojezierza Potudniowopomorskiego. Bogucki Wyd. Nauk., Poznań: 39-110.

Dobracka E., 2001. Szczegótowa mapa geologiczna Polski w skali 1:50 000 ark. Dobrowo, wraz z objaśnieniami. Państwowy Instytut Geologiczny, Warszawa.

Dobracka E., 2009. Szczegótowa mapa geologiczna Polski w skali 1:50 000 ark. Połczyn Zdrój, wraz z objaśnieniami. Państwowy Instytut Geologiczny, Warszawa.

Drozd J., Licznar M., Licznar S.E., Weber J., 2010. Gleboznawstwo z elementami mineralogii i petrografii. Wyd. Akademii Rolniczej we Wrocławiu, Wrocław.

Duff K., 1994. Natural Areas: an holistic approach to conservation based on geology. Geological and Landscape Conservation: $121-126$. London.

EEA [European Environment Agency], 2006. CORINE Land Cover. Online: http://www.eea.europa.eu/ (accessed 17.01.2015).

ESRI [Environmental System Research Institute] 2015. ArcGIS Resources. Online: resources.arcgis.com (accessed 23.10.2015).

Falińska K., 2012. Ekologia roślin. Bioróżnorodność, ochrona przyrody i ochrona środowiska. Wyd. Nauk. PWN, Warszawa.

Faliński J.B., 1969. Zbiorowiska autogeniczne i antropogeniczne. Próba określenia i klasyfikacji. Ekologia Polska, B, 15: 173-182.

Florek W., 1991. Postglacjalny rozwój dolin rzek środkowej części pótnocnego skłonu Pomorza. Wyd. WSP, Słupsk.

Gray M., 2004. Geodiversity: Valuing and Conserving Abiotic Nature. John Wiley and Sons, Chichester. 
Gray M., 2013. Geodiversity: Valuing and Conserving Abiotic Nature. 2nd Edition. John Wiley and Sons, Chichester.

Hjort J., Gordon J.E., Gray M., Malcolm L. Hunter Jr., 2015. Why geodiversity matters in valuing nature's stage. Conservation Biology 29 (3): 630-639.

Hjort J., Heikkinen K., Luoto M., 2012. Inclusion of explicit measures of geodiversity improve biodiversity models in a boreal landscape. Biodiversity Conservation 21: 34873506.

IMGW [Instytut Meteorologii i Gospodarki Wodnej], 2007. Mapa Podziału Hydrograficznego Polski, 1:50 000. Zakład Hydrografii i Morfologii Koryt Rzecznych, Instytut Meteorologii i Gospodarki Wodnej, Ministerstwo Środowiska, Narodowy Fundusz Ochrony Środowiska i Gospodarki Wodnej, Warszawa.

Jačková K., Romportl D., 2008. The relationship between geodiversity and habitat richness in Šumava. National Park and Křivoklátsko Pla (Czech Republic): a quantitative analysis approach. Journal of Landscape Ecology 1: 23-38.

Jaskulska A., Reynard E., ZwolinskiZb., 2013. Geodiversity assessment for environmental management of geomorphosites: Derborence and Illgraben, Swiss Alps. EGU General Assembly Conference Abstracts 15: 838.

Jedicke E., 2001. Biodiversität, Geodiversität, Ökodiversität. Kriterien zur Analyse der Landschaftsstruktur - ein konzeptioneller Diskussionsbeitrag. Naturschutz und Landschaftsplanung 33(2/3): 59-68.

Jenks G. F., 1967. The data model concept in statistical mapping. International Yearbook of Cartography 7: 186-190.

Jenness J., Brost B., Beier P., 2011. Land Facet Corridor Designer: extension for ArcGIS. Jenness Enterprises. Online: http://www.jennessent.com/arcgis/land_facets.htm (accessed 18.06.2015).

Karczewski A., 1989. Morfogeneza strefy marginalnej fazy pomorskiej na obszarze lobu Parsęty $w$ vistulianie (Pomorze Środkowe). UAM, Poznań, Geografia, 44.

Kistowski M., 2012. Prawne możliwości ochrony georóżnorodności i różnorodności krajobrazowej w warunkach polskich. Annales UMCS LXVII (2): 45-62.

Kłysz P., 1990. Mechanizm ksztattowania się strefy marginalnej fazy pomorskiej na obszarze Pojezierza Drawskiego. UAM, Poznań.

Kondracki J., 2000. Geografia regionalna Polski, PWN, Warszawa.

Kot R., 2006. Georóżnorodność - problem jej oceny i zastosowania w ochronie i kształtowaniu środowiska na przykładzie fordońskiego odcinka Doliny Dolnej Wisty i jej otoczenia. Towarzystwo Naukowe w Toruniu, UMK, Torun.

Kot R., 2014. The Point Bonitation Method for Evaluating Geodiversity: A Guide with Examples (Polish Lowland). Geografiska Annaler: Series A, Physical Geography 97(2): 375-393.

Leser H., 1997. Von der Biodiversität zur Landschaftsdiversität. Das Ende des disziplinären Ansatzes der Diversitätsproblematik. In: Erdmann K.-H. (ed.), Internationaler Naturschutz, Springer, Berlin Heidelberg New York, 145-175.

Lewandowski J., Heliasz Z., Chybiorz R., 2006. Szczegótowa mapa geologiczna Polski w skali 1:50 000 ark. Łubowo (197). Państwowy Instytut Geologiczny, Warszawa: 1-37.

Łowicki D., 2014. Ewaluacja krajobrazu na potrzeby planowania przestrzennego w Aglomeracji Poznańskiej. [in:] Współczesne metody badań krajobrazowych, Problemy Ekologii Krajobrazu, 38: 107-115.
Macias A., Bródka S., 2014. Przyrodnicze podstawy gospodarowania przestrzenia. PWN, Warszawa.

Marcinek R., Myczkowski Z., Siwek A., 2009. Możliwości wdrożenia Europejskiej Konwencji Krajobrazowej i problem zachowania dziedzictwa kulturowego poprzez kształtowanie krajowej polityki przestrzennej - rekomendacje do KZPK. In: Koncepcja Przestrzennego Zagospodarowania Kraju 2008-2033, ekspertyza na zlecenie Ministerstwa Rozwoju regionalnego, Kraków-Warszawa.

Marshal's Office [Urząd Marszałkowski Województwa Zachodniopomorskiego], 2015. Mapy glebowo-rolnicze dla gmin Rąbino, Połczyn-Zdrój, Tychowo, Czaplinek, Barwice i Borne Sulinowo.

Matuszkiewicz J.M., 2008. Geobotanical regionalization of Poland (Regionalizacja geobotaniczna Polski)., IGiPZ PAN, Warszawa. Online: https:/ / www.igipz.pan.pl/Regiony-geobotaniczne-zgik.html (accessed 25 September 2015).

Matuszkiewicz W., 1974. Teoretyczno-metodyczne podstawy badań roślinności jako elementu krajobrazu i obiektu użytkowania rekreacyjnego. Wiad. Ekolog. 20(1): 3-13.

Matuszkiewicz W., 2012. Przewodnik do oznaczania zbiorowisk roślinnych Polski. Wyd. Nauk. PWN, Warszawa.

Matuszkiewicz W., Faliński J.B., Kostrowicki A.S., Matuszkiewicz J.M., Olaczek R., Wojterski T., 1995. Potencjalna roślinność naturalna Polski. Mapa przeglądowa 1:300 000. Arkusze 1-12, IGiPZ PAN, Warszawa.

Mazurek M., 2010. Hydrogeomorfologia obszarów źródliskowych (dorzecze Parsety, Polska NW). Wydawnictwo Naukowe UAM, Poznań, Ser. Geografia 92, pp. 304.

Mazurek M., Najwer A., Borysiak J., Gudowicz J., Zwoliński $\mathrm{Zb}$., 2015. From geodiversity and biodiversity through geoheritage to geoconservation; case study for the Dębnica River drainage basin (Poland). EGU General Assembly 2015 Conference Abstracts 17: 7870.

Mazurek M., Paluszkiewicz R., 2013. Formation and development of a 1st-order valley network in postglacial areas (the Dębnica catchment). Landform Analysis 22: 75-87.

Najwer A., Reynard E., Zwoliński Zb., 2014. GIS and Multi-criteria evaluation (MCE) for landform geodiversity assessment. EGU General Assembly 2014 Conference Abstracts, 16, 906.

Najwer A., Zwoliński Zb., 2014a. Semantyka i metodyka oceny georóżnorodności - przegląd i propozycja badawcza. Landform Analysis 26: 115-127.

Najwer A., Zwoliński Zb., 2014b. The landform geodiversity assessment method - a comparative analysis for Polish and Swiss mountainous landscape. IGU 2014 Book of Abstracts, 1201.

NGIA [National Geospatial-Intelligence Agency], 2004. Performance specification digital terrain elevation data (DT$\mathrm{ED}^{\mathrm{TM}}$ ). National Geospatial-Intelligence Agency, National Center for Geospatial Intelligence Standards (NCGIS), Reston, VA.

Ollier C., 2012. Problems of geotourism and geodiversity. Quaestiones Geographicae 31(3): 57-61.

Paluszkiewicz R., 2013. The developmental stages of an accumulative cone of dry valley as an indication of change in natural environment conditions (Western Pomerania). Quaestiones Geographicae 32(1): 15-20.

Parks K.E., Mulligan M., 2010. On the relationship between a resource based measure of geodiversity and broad scale biodiversity patterns. Biodiversity and Conservation 19(9): 2751-2766.

Pauditšová E., Reháčková T., 2010. Landscape-ecological proposals for the increase of ecological stability in the 
contact zone between settlements and agricultural landscape. Problemy Ekologii Krajobrazu 28: 45-54.

Pawlaczyk P., Herbich J., Holeksa J., Szwagrzyk J., Świerkosz K., 2003. Rozpoznawanie siedlisk przyrodniczych na podstawie danych opisu taksacyjnego lasu. Ministerstwo Środowiska RP, Warszawa. Online: http:/ / www.kp.org.pl/n2k/ files/algorytmy_lesne_n2k.pdf (accessed 15.05.2015).

Pellitero R., González-AmuchasteguiM.J., Ruiz-Flaño P., Serrano E., 2010. Geodiversity and Geomorphosite Assessment Applied to a Natural Protected Area: the Ebro and Rudron Gorges Natural Park (Spain). Geoheritage 3: 163-174.

Popielski W., 2000. Szczegótowa mapa geologiczna Polski w skali 1:50 000 ark. Barwice. Archiwum Geologiczne PIG-BIP Warszawa.

Prusinkiewicz Z., Bednarek R. 1991. Gleby. In: Starkel L. (ed.), Geografia Polski. Środowisko przyrodnicze. PWN, Warszawa: 387-412.

Ratajczak-Szczerba M., 2013. Geo- i bioróżnorodność doliny Srodkowej Noteci i doliny Dolnej Gwdy szansą rozwoju geoturystyki. Acta Geographica Silesiana 14: 71-86.

Richling A., Solon J., 2011. Ekologia Krajobrazu. Wyd. Nauk. PWN, Warszawa.

Roo-Zielińska E., 2014. Wskaźniki ekologiczne zespołów roślinnych Polski. IGiPZ PAN i Wyd. Akademickie SEDNO, Warszawa.

Saaty T.L., 1977. A Scaling Method for Prioritiesin Hierarchical Structures. Journal of Mathematical Psychology 15: 234-281.

Saaty T.L., 1980. The analytic hierarchy process. McGraw-Hill, New York.

Saaty T.L., 1994. Fundamentals of Decision Making. RSW Publications, 1994.

Science for Environment Policy, 2015. Ecosystem Services and the Environment. In-depth Report 11 produced for the European Commission, DG Environment by the Science Communication Unit, UWE, Bristol. Online: http://ec.europa.eu/science-environment-policy (accessed 28.12.2015).

Serrano E., Ruiz-Flaño P., 2009. Geomorphosites and Geodiversity. In: Reynard E., Coratza P., Regolini-Bissig G. (eds.), Geomorphosites. Verlag Pfeil, Munich: 51-63.

Sikorska E., 1999. Siedliska leśne. Cz. I. Siedliska obszarów niżowych. Wyd. Akademii Rolniczej im. H. Kołłątaja w Krakowie, Kraków.

Silva J.X., 2004. Geodiversity: Some simple geoprocessing indicators to support environmental biodiversity studies. Online: www.directionsmag.com/articles/geodiversity-some -simple-geoprocessingindicators-to-support-environmental-/123803 (accessed 17.06.2015).

Solon J., Chmielewski T.J., Myga-Piątek U., Kistowski M. 2014. Przygotowanie opracowania pt. "Identyfikacja i ocena krajobrazów - metodyka oraz główne założenia". Zadanie III.1. Opracowanie szczegółowej instrukcji postępowania, prowadzącej wykonawcę audytu od rozpoczęcia prac do pełnego zakończenia. Wersja 02. Instytut Geografii i Przestrzennego Zagospodarowania im. S. Leszczyńkiego, pp. 104. Online: http://ochronaprzyrody. gdos.gov.pl/publikacje-i-materialy-promocyjne-2

Sołowiej D., 1992. Podstawy metodyki oceny środowiska przyrodniczego człowieka. Wyd. Nauk. UAM, Poznań.

Speak A., Mizgajski A., Borysiak J., 2015. Allotment gardens and parks: Provision of ecosystem services with an emphasis on biodiversity. Urban Forestry and Urban Greening 14: $772-781$.
Sukopp H., 1972. Wandel von Flora und Vegetation in Mitteleuropa unter dem Einfluss des Menschen. Berichte über Landwirtschaft 50(1): 112-139.

Szpikowski J., 2010. Antropogeniczne przeksztatcenia rzeźby zlewni Perznicy w neoholocenie (Pojezierze Drawskie, dorzecze Parsęty). Wydawnictwo Naukowe UAM, Poznań, Ser. Geografia 91.

Szpikowski J., Szpikowska G., Domańska M., 2015. Old melioration systems: the influence onto functioning of geoecosystems of river valleys in the Parsęta basin (NW Poland). Quaestiones Geographicae 34(3): 57-68. DOI 10.1515/ quageo-2015-0024

Thomas M.F., 2012. A geomorphological approach to geodiversity - Its applications to geoconservation and geotourism. Quaestiones Geographicae 31(3) 81-89.

Ustawa krajobrazowa, 2015. Ustawa z dnia 24 kwietnia 2015 r. o zmianie niektórych ustaw w związku ze wzmocnieniem narzędzi ochrony krajobrazu. Dz.U. 2015, poz. 774.

Virtanen R., Luoto M., Rämä T., Mikkola K., Hjort J., Grytnes J-A., Birks H.J.B., 2010. Recent vegetation changes in the high-latitude tree-line ecotone are controlled by geomorphological disturbance, productivity and diversity. Global Ecology and Biogeography 19: 810-821.4

Water Law [Prawo wodne], 2001. Ustawa z dnia 18 lipca 2001 r. Prawo wodne. Dz.U. 2001 nr 115 poz. 1229.

Weiss A., 2001. Topographic Position and Landforms Analysis. Poster presentation, ESRI User Conference, San Diego, CA.

Winiecki J., 2012. Transformacja postkomunistyczna. Wydawnictwo C.H. Beck, Seria Ekonomia. Warszawa, pp. 311.

Zwoliński Zb., 2004. Geodiversity. In: Goudie A. (ed.), Encyclopedia of Geomorphology, Routledge: 417-418.

Zwoliński Zb., 2007. Mobilność materii mineralnej na obszarach paraglacjalnych, Wyspa Króla Jerzego, Antarktyka Zachodnia. Wydawnictwo Naukowe UAM, Ser. Geografia 74 .

Zwoliński Zb., 2008. Designing a map of the geodiversity of landforms in Poland. IAG and AIGEO International Meeting, Environmental Analysis and Geomorphological Mapping for a Sustainable Development, Addis Ababa, Ethiopia, February 26, 2008. Abstract Book, p. 18-22.

Zwoliński Zb., 2009. The routine of landform geodiversity map design for the Polish Carpathian Mts. In: Rojan E., Łajczak A. (eds.), Geoecology of the EuroasiaticAlpids. Landform Analysis 11: 79-87.

Zwoliński Zb., Gudowicz J., 2015. Geomorphometric analysis of morphoclimatic zones on the Earth. In: Jasiewicz J., Zwoliński Zb., Mitasova H., Hengl T. (eds.), Geomorphometry for Geosciences, Adam Mickiewicz University in Poznań - Institute of Geoecology and Geoinformation, International Society for Geomorphometry, Poznań: 19-22.

Zwoliński Zb., Kostrzewski A., Stach A., 2008. Tło geograficzne współczesnej ewolucji rzeźby młodoglacjalnej. In: Starkel L., Kostrzewski A., Kotarba A., Krzemień K. (eds.), Wspótczesne przemiany rzeźby Polski, Wydawnictwo IGiGP UJ, Kraków: 271-275.

Zwoliński Zb., Stefańska E., 2015. Relevance of moving window size in landform classification by TPI. In: Jasiewicz J., Zwoliński Zb., Mitasova H., Hengl T. (eds.), Geomorphometry for Geosciences, Adam Mickiewicz University in Poznań - Institute of Geoecology and Geoinformation, International Society for Geomorphometry, Poznań: 273-278. 